\title{
Wage Garnishment in California: A Study and Recommendations ${ }^{\dagger}$
}

\section{George Brunn*}

T OLIYWOOD HAS BROUGHT us a familiar picture of the Western sheriff, 11 with his ten-gallon hat, star on shirt, riding after the black-hatted criminal or outdrawing him in the middle of the town's dusty main street. Today's deputy sheriff in California is likely to wear a business suit and to carry a briefcase instead of a gun. Rather than pursuing criminals, he may spend his career doing nothing more glamorous than serving papers in civil lawsuits-summonses, subpoenas, writs, and orders. As law and order followed the flag, papers followed the law.

Lots of papers. The San Francisco Sheriff's Office has a civil department with eleven field deputies and sixteen persons in the office just for serving papers. In the first two months of 1965 the deputies made more than 5,900 services, among them over 3,700 levies under writs of attachment and execution. Most of these levies-seventy-five to eighty per cent -were wage garnishments. ${ }^{1}$ The sheriff's business is booming; he makes more levies than ever and collects over a million dollars a year for creditors. ${ }^{2}$ Society subsidizes the sheriff's collection work; the cost of operating the civil department runs more than double the amount of fees the department receives. ${ }^{3}$

To the deputy, wage levies are mainly a job; to the creditor, a useful collection device; to the employer who must process them, a nuisance and an expense; to the debtor, a humiliating experience that may bring

$\dagger$ Based on a study made for the Center for the Study of Law and Society, University of California, Berkeley. Bar.

*A.B., 1947, Stanford University; LL.B., 1950, Stanford University ; Member, California

1 Data obtained from Carl Olson, Chief Deputy, Civil Department, Office of the Sheriff, City and County of San Francisco [hereinafter cited Olson data]. Writs of attachment and execution, including garnislments, must be levied by a sleriff, constable, or marshall. Cax. Code CTv. Proc. $\$ \S 540,542,682$. The ratio of wage levies to levies on other property is Olson's estimate. A separate survey corroborates the ratio. See Appendix B, infra (taking the number of levies where the type of property levied against was known, 47 out of 68 levies, or almost $70 \%$, were wage garnislments; in executions the ratio is substantially higher).

2 Trust fund disbursements by the San Francisco Sheriff's Office rose from $\$ 547,000$ in fiscal 1953-54 to $\$ 1,144,000$ in fiscal 1963-64. Personal property attachments and executions totaled 1356 in February 1953 and 1781 in February 1965. Executions rose sharply while attachments declined. Of the February 1953 levies, 784 were attacliments and 572 executions; in February 1965 there were 696 attachments and 1085 executions. Olson data. Compare Appendix B infra.

3 Note 48 infra. With respect to fees, see text accompanying note 46 infra. 
serious hardship in its wake. Society has a major stake in the garnishment process, which is not only a creature of law but an activity of government. Society has a legitimate concern that legal debts be paid; society also has a legitimate concern that the collection tools it fashions and whose use it sanctions do not cause undue distress and hardship. How well garmishment serves these various competing interests is the question underlying this study.

The study first considers the operation of wage garnishment in California. Next it reviews the equivalent laws of other states, especially with respect to the amount of earnings exempt from garnishment. Then it discusses major factors pertinent to a garnishment policy, among them the relation of garnishment to employment, bankruptcy, and consumer credit. The final section includes several recommendations.

\section{GARNISHMENT STATUTES}

\section{A. California}

The words "attachment," "execution," and "garnishment" have a formidable ring. Their meaning is simple enough. Both attachment and execution refer to the seizure of a defendant's property by legal process; attachment takes place before judgment "as security for the satisfaction of any judgment that may be recovered"; ${ }^{4}$ execution may be had after judgment for its enforcement. "The term "garnishment" is little used in Cahiforma statutes, but in common legal parlance refers to the use of either attachment or execution to reach property of the debtor which is in the possession of a third person. ${ }^{6}$ Among such items of property may be wages payable to a debtor by his employer-hence the term "wage garnishment."

The key California provision that limits garmishment of wages is Code of Civil Procedure section 690.11:7

4 Car. Code Crv. Proc. \& 537.

6 Car. Code Crv. Proc. $\S 681$.

${ }^{6}$ See Kimball v. Richardson-Kimball Co., 111 Cal. 386, 393, 43 Pac. 1111 (1896). See also RESTATEMTENT, JUDGMENTS $\S \S 35,36$ (1942). A "special note" to § 36 states: "A proceeding by which the plaintiff is enabled to reach and to apply to the satisfaction of his claim a debt owing to the principal defendant is ordinarily called garnishment, and the principal defendant's debtor is called the garnishee. The word 'garnish' means 'warn': the garnishee is warned that he is not to pay his debt to the defendant, his creditor, but to the plaintiff. In some of the New England States the proceeding is called 'trustee process,' and the defendant's debtor is called the "trustee." "

7 California Code of Civil Procedure $\S 690.10$ provides a special exemption for the earnings of "seamen, seagoing fishermen and sealers" in the amount of $\$ 150$ or $\$ 300$ depending on conditions specified in the section. 
One-half of the earnings of the defendant or judgment debtor received for his personal services rendered at any time within 30 days next preceding the levy of attachment or execution shall be exempt from execution or attachment without filing a claim for exemption as provided in Section 690.26 .

All of such earnings, if necessary for the use of the debtor's family, residing in this State, and supported in whole or in part by such debtor unless the debts are: (a) incurred by such debtor, his wife or family, for the common necessaries of life; or (b) incurred for personal services rendered by any employee, or former employee, of such debtor.

Prior to causing any levy of attachment on earnings of the defendant received for his personal services, the plaintiff shall file with the levying officer an affidavit that the defendant whose earnings are to be attached has been served with a copy of the summons and of the complaint or that the defendant has been given notice pursuant to Chapter 5 (commencing with Section 1010) of Title 14 of Part 2 of this code that a writ of attachment on his earnings will issue after eight days from the date of such notice. Such notice shall only be required on the first writ of attachment on earnings.

Two features of this section are of fairly recent origin. First, the provision that half the earnings are automatically exempt was enacted in $1955 .^{8}$ Prior to that time the debtor had to file an affidavit of exemption with the levying officer in order to obtain any exemption at all. Debtors are still required to follow this procedure if they want to get more than half of their earnings exempted from levy. ${ }^{\circ}$

Second, the last paragraph of section 690.11 was added in $1963 .^{10}$ It applies only to attachments (not to executions) and is of very limited benefit to debtors: They simply get one more "pay or face the consequences" notice. The provision is of greater help to creditors who are given sanction to send the debtor a threatening notice "that a writ of attachment on his earmings will issue after eight days from the date of this notice." The bill which ultimately became the 1963 amendment started out with entirely different provisions: In its original form it exempted all earnings from levy; an amended version exempted all earnings from attachment and seventy-five per cent (with a maximum of 200 dollars a week) from execution. ${ }^{11}$ Subsequent amendments dropped all changes in exemptions and substituted the notice provision.

Soon after enactment of this provision a question arose whether collection agencies could give the notice required by section 690.11 . Collection agencies are prohibited from practicing law, from using forms

8 Cal. Stats. 1955, ch. 793, § 3, at-1393. See also Cax. Code CIv. Proc. \$§ 542(5), 543, $682(1), 682.1,688,710$.

o Cal. Code Civ. Proc. \$ 690.26.

10 Cal. Stats. 1963, ch. 1540, § 1, at 3124 .

11 Assembly Bill 482 (1963). The author was Assemblyman Foran. 
resembling legal forms, and from engaging in any unfair or misleading practices. ${ }^{12}$ The Collection Agency Licensing Bureau takes the position that the notice may be sent by the collection agency's attorney but not by the agency itself. ${ }^{13}$ The Bureau's position was sustained by the Superior Court in Los Angeles County, whose judgment was not appealed and has become final. ${ }^{14} \mathrm{~A}$ bill introduced in the 1965 general session of the legislature would have undone the decision and let collection agencies give the notice. ${ }^{15}$

\section{1. "Common Necessaries" and Exemption Claims}

In practical operation section 690.11 exempts only half the wages of the great bulk of debtors-for example, while San Francisco's sleriff levied 1781 attachments and executions in February 1965, he received only 52 exemption claims during that period, a ratio that he considers typical..$^{16}$ Two related factors account for this: the "common necessaries" clause of the section and the practical difficulties in obtaining an exemption for more than half of the wages.

Reported decisions on the meaning of "the common necessaries of life" are scant, ${ }^{17}$ for the very good reason that few debtors can afford to litigate this issue at all, let alone fight an appeal. In Los Angeles Finance Co. v. Flores ${ }^{18}$ (where the debtor was represented by the public defender), the debtor's wife had bought him a gold wrist watch for his birthday. The court held this was not one of the common necessaries of life. Noting "the general policy of the courts of this state to give a liberal construction to exemption statutes in favor of the debtor,"10 the court said that the question of what is a common necessary

involves a determination of whether or not it is such an article that in the hands of anyone it is to be regarded universally, or substantially so, as necessary to sustain life. Obviously, the Legislature, cognizant

12 CAL. BUS. \& Prof. CODE $\$$ 6947(h), (k). A regulation of the Collection Agencies Licensing Bureau prohibits such agencies from employing "instruments simulating forms ... of notice pertaining to judicial proceedings ... o other than to notify the debtor that the matter will be referred to its attorney for appropriate action." 16 CAL. ADMIN. CODE \& $628(b)(7)$.

13 Stores Collection Bureau v. Powers, Los Angeles Super. Ct., No. 831522 (1965). See also Assembly Interim Comm. on the Judiciary, Proceedings on Attachments 44 (June 23, 1964) [hereinafter cited Hearings].

14 Stores Collection Bureau v. Powers, supra note 13. Judgment was entered on Jan. 22, 1965. The judgment also prohibits collection agencies from sphitting attorneys' fees awarded in their cases with their attorneys.

15 Assembly Bill 2925 (1965) (introduced by Assemblyman Foran). The bill was not enacted.

16 Olson data.

17 See generally Seid, Necessaries-Common or Otherwise, 14 HAstnvGs L.J. 28 (1962).

18110 Cal. App. 2d Supp. 850, 243 P.2d 139 (1952).

19 Id. at 854,243 P.2d at 142 . 
of the fact that to the great majority of persons supporting a family the earnings of the past 30 days are required for such basic things as food, heat, shelter, etc. (common to all) desired to make sure that these earnings shall not be taken to pay for something less basic. ${ }^{20}$

Los Angeles Finance Co. v. Flores has been of little lielp to debtors. The half of the wages that is not automatically exempt can be attached by a routine allegation in the affidavit for attachment that the action is brought to collect a debt incurred for the common necessaries of life; ${ }^{21}$ for a writ of execution not even an affidavit is needed. If the debtor wants to get that lialf of his earnings exempted, his road begins by his filing an exemption affidavit. He first has to obtain the forms from the sheriff; they are not given to him at the time lis wages are garnislied. ${ }^{22} \mathrm{He}$ completes them in duplicate, "specifying the section or sections of this code on which he relies for his claim to exemption, and all facts necessary to support his claim ..." and returns the affidavit to the levying officer. ${ }^{28}$ Does he then get his wages? No. Then he waits at least five days. During that time the creditor may file a counter-affidavit. ${ }^{24}$ If the creditor doesn't, the wages are released. ${ }^{25}$ But if he does, they remain tied up for at least

$20 I d$. at 856,243 P.2d at 143-44 (1952). This is the latest word on the subject. The court could find only three earbier cases dealing with this clause. White v. Gobey, 130 Cal. App. 789, 19 P.2d 876 (1933), held that clothing bought by the defendant's wife before marriage did not come within the "common necessary" limitation because, having been bought before she became his wife, the articles were not "necessities . . . used for the very maintenance of the debtor's family, for food, clothing and the like . . . ." Id. at 792. In Evans v. Noonan, 20 Cal. App. 288, 293, 128 P. 794, 795 (1912), the court said common necessaries of life include "besides food, clothing and sbelter such medical attentions in cases of illness as are absolutely requisite to relieve physical suffering and pain and to overcome and conquer disease, if by such attentions it can be done." The third case was an unreported decision, also involving a watch purchase, which Flores, in effect, overruled.

It should also be noted that the exemption provisions of Cahifornia Code of Civil Procedure, $\$ 690.11$, do not apply to alimony, child support, and attorney's fees in divorce actions. McIntosi v. McIntosh, 209 Cal. App. 2d 374, 26 Cal. Rptr. 28 (1962); Henry v. Henry, 182 Cal. App. 2d 707, 6 Cal. Rptr. 418 (1960).

21 CAI. Code CIv. Proc. \$ 538. This section also provides that no attachment may be issued where the principal claimed is below $\$ 75$. Assembly Bill 1127, passed in the 1965 session, Cal. Stat. 1965, ch. 668, § 1, raises this to $\$ 125$. Attachment in California is available in (1) actions on unsecured contracts, express or implied, (2) support actions, (3) contract and tort actions against nonresidents or persons absent from the state or who conceal themselves to avoid service, (4) unlawful detainer actions, (5) tax collection suits, and (6) suits by the state or any political subdivision to recover funds expended in certain narcotics investigations. CAI. CODE CTv. Proc. \& 537. None of the limitations applicable to attachment apply to executions.

22 The San Francisco Sheriff's Office advised the author that at one time it supplied debtors with affidavit forms at the time of the wage levy, but discontinued this practice following objections from collection agencies.

23 CaI. Code CTv. Proc. § 690.26(1).

24 CaI. Code Civ. Proc. $\$$ 690.26(3).

25 Cat. Code CTv. Proc. $\$$ 690.26(4). 
five more days. Durmg that time either party may move to have the exemption claim heard in court. If no one makes such a motion the wages are then released. ${ }^{26}$ If a motion is made, the levy stays in effect pending the hearing and the money remains in the hands of the sheriff. ${ }^{27}$ The hearing is to be within fifteen days after the making of the motion. ${ }^{28}$ Thus, as much as twenty-five days may elapse between the garnishment and the hearing.

When the claim for exemption finally comes up in court, the debtor has the burden of proof. ${ }^{29}$ That means he must prove both that the debt was not incurred for the common necessaries of hife and that he needs all of his earnings to support his family..$^{30}$ No wonder exemption claims are infrequent. .

The special treatment of debts for "common necessaries" is difficult to justify. It can be argued that those who sell essentials should have better means of collecting their debts than companies which extend credit for unessential or luxury purchases. The other side of the picture is that the statute puts the prudent (or poor) family which buys only essentials into a worse position than the family that buys nonessential items on credit. For example, a big medical bill could lead to garmshments ${ }^{31}$ while a debt resulting from the acquisition of a luxury car might be exempt from execution on wages-at least where the debtor is sophisticated in the use of the exemption provisions. Thus, to the extent that the distinction between debts for "the common necessaries of hife" and other debts really works, the results are paradoxical.

In many cases the distinction disappears in the day-by-day operation of the statute as it affects people in debt. Whatever the origin of their debt, the wage exemption is limited to fifty per cent except for the rare debtor who can successfully follow the exemption steps, take the time out from work to do so, and avoid falling further into debt while he waits for his earnings to be released. ${ }^{32}$ As will be discussed below, ${ }^{33}$ a fifty

${ }^{26}$ Cad. Code Civ. Proc. \$ 690.26(5), (6).

27 CaL. Code Crv. Proc. \$ 690.26(8).

28 CaL. Code Civ. Proc. § 690.26(5).

29 Cad. Code Crv. Proc. § 690.26(9); Perfection Paint Prod. v. Johnson, 164 Cal. App. 2d 739, 741, 330 P.2d 829, 831 (1958).

30 See Seid, supra note 17 , at 37 .

31 Hearings 82.

82 See text accompanying note 16 supra. Discussion with Judge Robert J. Drewes, Presiding Judge of the San Francisco Muricipal Court, confirms that exemption hearings are infrequent. An examination by the author of 100 cases filed in that court in January 1964, showed at lcast 47 wage levies (8 attachments, 39 executions and California Code of Civil Procedure $\$ 710$ proceedings) in 15 cases. In none was an exemption hearing either moved for or had.

38 Text accompanying note 85 infra. 
per cent exemption seems neither: adequate nor in accord with the legislative objective.

The "common necessaries" rule embodied in section 690.11 is uncommon. Only Idaho, Montana, Nevada, and Oregon apply variations of the California provision. ${ }^{34} \mathrm{New}$ Mexico repealed its "necessaries" exception in $1961 .^{35}$ Delaware and South Carolina use a more perceptive approach to the question of necessaries. In Delaware (New Castle County), ninety per cent of wages are exempt and the excess can be reached only for debts incurred "on account of the purchase of food, provisions and articles used in the home, commonly designated as the necessaries of life, and to taxes owing to the State of Delaware." ${ }^{\text {30 }}$ South Carolina provides for a one hundred per cent exemption but permits a levy, on court order, on fifteen per cent of the salary (but not more than one hundred dollars) if the judgment is for the balance due on "food, fuel or inedicine accounts. ${ }^{387}$

\section{Multiple Levies}

Another feature of California's wage garnishment procedure is that it permits multiple levies, that is, a creditor can levy as frequently as he wants to-every week, for exaniple. Other creditors may levy as well. ${ }^{38}$

Even collection agencies favor some limitation on the number of levies by a smgle creditor within a given period of time. C. H. McCarty,

34 IDAHO CODE ANN. § 11-205(7) (1947) (exemption limited to 50\% where debt is for actual "necessaries"); MoNx. Rev. CoDes ANN. \$ 93-5816 (1964) (limited to 50\% where debt is for gasoline or "common necessaries"); NEv. REv. Stat. \$ 21.090(h) (1963) (follows California wording as to "the common necessaries of life"-50\% limitation); ORE. REv. STAT. $\$ 23.180$ (1961) ( $50 \%$ of earnings subject to execution where debt is incurred for "family expenses"). See also NEB. REv. STAT. \$§ 25-1557, 25-1558 (1964). The latter section grants a $90 \%$ wage exemption. The former provides, in part: "Nothing in this chapter shall be construed to exempt from execulion or attachment property of the value of more than five hundred dollars for any debt contracted by any person in the purchase of the actual necessaries of life ...." These provisions, taken together, apparently do not himit the operation of the wage exemption, but refer to other property which a debtor may claim exempt. Compare Neb. Rev. Star. \& 25-1552 (1964); Lyons v. Austin, 126 Neb. 248, 252 N.W. 908 (1934).

35 N.M. Laws 1961, ch. $8, \S 1$, at 21.

36 Des. Code ANN. tit. 10, \& 10-4913(b) (1953). In Delaware's other two counties $60 \%$ of wages are exempt. DEL. CODE ANN. tit. 10, § 10-4913(a) (1953). The practice of having different exemption laws for different counties within a state is limited to Delaware and Maryland. MD. ANN. CODE art. 9, $\$ \S 31,31 \mathrm{~A}$ (Supp. 1965). In those two states statutes of many kinds have local variations.

37 S.C. CODE § 10-1731 (1962). A 1964 law permits attachment of wages for medical care, exelusive of doctor's fees, under certain conditions. S.C. Laws 1964, No. 950, at 2194; S.C. CODE \& 71-145 (Supp. 1965).

38 Hearings 19-20, 50-52. 
legislative representative for the California Association of Collectors, testified at a legislative committee hearing: "I would like the Committee to examine consecutive garnisliment. I don't believe in this and the Association I represent don't [sic] believe in it and I think you have it in writing from Mr. Weissman. This is and can be a very vicious practice. . . . This can really kill a man. He doesn't have a chance."39 However, Joseph J. Weissman, speaking for the same group as McCarty, was willing to limit only the number of attachment levies (to one in any thirty-day period), not the number of execution levies. ${ }^{40}$ This would be a meaningless change since multiple garnishments occur mainly under writs of execution rather than under writs of attachment. A survey by the author of one hundred cases in the San Francisco Mumcipal Court disclosed one case of more than one wage garnishment by virtue of attachnent, while writs of execution in thirteen cases produced thirty-mine wage levies. The main reasons for this difference are: (1) Most collection suits are quickly reduced to judgment, usually by default. In many of them little time elapses-often no more than the statutory ten days ${ }^{41}$-between service of the complaint and rendition of judgment. Hence the occasions for multiple attachment levies are limited. (2) The use of writs of attachments in collection suits has been decliming. ${ }^{42} \mathrm{~A}$ number of collection agencies do not attach wages before judgment. ${ }^{43}$

Sheriffs are also unhappy about frequently repeated levies. ${ }^{44}$ Carl Olson, Chief Deputy, Civil Department, San Francisco Sheriff's Office, notes that when he is instructed to levy every week, he may have to make a levy before he receives the return on the previous week's garnislment. Thus he may be required to make a levy that is both unnecessary and risky. Olson also notes that multiple levies add to the debtor's expense. While the sheriff's fees are initially paid by the creditor, they become part of the costs of the case chargeable against the judgment debtor. ${ }^{45}$ The sheriff's fees for each wage levy are two dollars ${ }^{46}$ plus thirty-five cents per mile from his office to the point of service, one way, ${ }^{47}$ plus one

89 Hearings 49-50. (Emphasis added.)

40 Hearings 52. Weissman would also let each creditor continue to levy. Id. at 52-53.

41 Cax. Code Civ. Proc. \$§ 585, 407.

42 Note 2 supra.

43 Hearings 16 (testimony of Robert C. Kopriva, president of the Associated Credit Bureaus of California. Kopriva said: "We don't feel it's fair."). The speed with which the complaint can be reduced to judgment is probably also a factor.

44 Olson data.

45 Caz. Code Civ. Proc. \$\$ 1031, 1033.7.

16 CAx. Gov's CODE \& 26734.

47 Cax. Gov't Code $\$ 26746$. 
per cent of the amount collected..$^{48}$ In addition, there is a clerk's fee of two dollars for issuing a writ of execution. ${ }^{4 \theta}$

\section{B. Other States.}

Garnishment of wages, although it has roots going back to colonial ${ }^{50}$ and even medieval times, ${ }^{61}$ is a statutory procedure. ${ }^{62}$ The varying state laws, observes one writer, "are about as individual as snowflakes." different approaches to wage exemptions in each state are illustrated by the summary in Appendix A to this article. Upon closer examination certain characteristics emerge from the statutory jumble.

\section{Exemptions in Large States}

In large states exemptions tend to be high. Comparmg Cahifornia, Florida, Illinois, Massachusetts, Michigan, New Jersey, New York, Ohio, Pennsylvania, and Texas-the ten most populous states-Cahfornia is among the least generous. Half of these ten states exempt ninety or one hundred per cent of earnings (Florida, New Jersey, New York, Peunsylvania, and Texas), Ilinois exempts eighty-five per cent and two others, Michigan and Massachusetts, have a one hundred per cent exemption prior to judgment. ${ }^{54}$

Thus, a married man earning one hundred dollars a week would have the following exemption in these states:

48 CAx. Gov'T Code \& 26739. Despite these fees, the county seems to pay a substantial portion of the collection costs. Carl Olson of the San Francisco Sheriff's Office reports that in 1963-64 his office received $\$ 113,554$ as fees from all services. He estimates the cost of operating his office as exceeding $\$ 250,000$ annually. In Los Angeles County, the cost of operating the Sheriff's Civil Division is about $\$ 430,000$ per year. The Division receives for fees and mileage approximately $\$ 220,000$. To what extent should society subsidize the collection process? Raising fees would increase the burden on the debtors unless at the same time creditors are required to pay part of the cost. Utah provides that such costs are not to be charged to the judgment debtor. UTAF CODE ANN. \& 78-23-1(7) (1953). In Delaware, the debtor's cost liability is limited to $\$ 0.90$ per levy. DeI. CoDE ANN. tit. 10, $₹ 10$ 4913(c) (1953). A reduction in multiple levies would tend to alleviate the cost burden both of the debtor and of the community.

49 CAL. Gov'T CODE $\& 26828$. There may be several levies under a single writ: A writ can remain in effect for 60 days before it has to be returned. CaI. Code Civ. Proc. $\& 683$.

50 Mussman \& Riesenfeld, Garnishment and Bankruptcy, 27 Mins. L. REv. 1, 9-10 (1942).

51 Riesenfeld, Collection of Money Judgments in American Law, 42 Iowa L. Rev. 155 (1957).

62 See Sanders v. Armour Fertilizer Works, 292 U.S. 190 (1934).

63 Seid, supra note 17, at 33.

64 Among this group of states, the post-judgment exemption could be as low as California's only in Massachusetts and Michigan. Depending on the circumstances it may be higher or lower in those states. See notes 199, 201 infra and accompanying text. 
TABLE 1

Wage Exemption in Ten Largest States gor Married Person Earning $\$ 100$ PER WeEK 55

\begin{tabular}{lcc}
\hline \multicolumn{1}{c}{ State } & Before Judgment & After Judgment \\
\hline Florida & $\$ 100$ & $\$ 100$ \\
Pennsylvania & 100 & 100 \\
Texas & 100 & 100 \\
Massachusetts & 100 & 50 \\
Michigan & 100 & 50 \\
New Jersey & 90 & 90 \\
New York & 90 & 90 \\
Illinois & 85 & 85 \\
Ohio & 75 & 75 \\
California & 50 & 50 \\
\hline
\end{tabular}

It should be added that some states do not expressly prohibit wage levies prior to judgment but unlike California do not make any attachment process prior to judgment freely available in contract actions, limiting the attachment remedy to special circumstances. ${ }^{56}$ To the extent that these limitations work, ${ }^{57}$ they tend to give debtors a one hundred per cent wage exemption before judgment.

\section{The Trend of Statutory Changes}

Wage exemption statutes change frequently, as a comparison with their versions of a decade ago discloses. ${ }^{58}$ The direction of the change is almost uniformly toward increasing the exemption of the debtor; at least twenty states did so between 1954 and $1964 .{ }^{59}$ Some of these states, and others as well, also made changes in garnishment procedures. Among

55 The Michigan computations assume that the garnishment is the first in the case; the California figures are based on the $50 \%$ exemption-because of its prevalence-discussed in text at p. 1217; the Ohio exemption is computed positing the Ohio practice as set forth in Note, Garnishment of Wages in Ohio, 21 U. CIvc. L. REv, 268, 274-75 (1952). It should be noted that in both Michigan and Ohio judgment debtors can, in effect, obtain substantially higher exemptions under statutory conciliation and trusteeship provisions, respectively. Notes 76-78 infra and accompanying text. Under the Michigan procedure, partial payment orders made by the court customarily require the debtor to pay $10 \%$ of net income if married, 15\% if single. FUSFEID, DoN'T GET GARNISEEED! 16 (Michigan State University, Labor and Industrial Relations Center, undated).

56 See generally 6 Adr. JUR. 2d Attachment \& Gamishment $\$ \S 218-51$ (1963).

57 For an indication that they may not work well, see Note, Garnishment in KentuckySonve Defects, $45 \mathrm{Kx}$. L.J. 322 (1956-57).

58 Compare Abraliams \& Feldman, The Exemption of Wages from Garnishment, $3 \cdot \mathrm{DE}$ Paur L. REv. 153 (1954), with Note, State Wage Exemption Laws and the New Iowa Statute, 43 Iowa L. REv. 555 (1958).

50 One state, Iowa, decreased the exemption. See Note, State Wage Exemption Lares and the New Iowa Statute, 43 Iowa L. REv. 555 (1958). 
these states were California, as discussed above, and New York. ${ }^{\circ 0}$ Increases were enacted particularly often in states where the exemption is (or had been) tied to dollar amounts. ${ }^{61}$ Dollar figures in such statuteseven as maxima or minima - tend to get out of date; during an inflationary period, such as the one following World War II, they rapidly become inadequate. Thus they require continuous legislative attention, and even then revision tends to lag. When revision is not forthcoming, the exemption sometimes approaches meaninglessness, as in Kentucky where the ceiling is 67.50 dollars a month. ${ }^{62}$ Some years ago a writer observed that when the Kentucky statute was first enacted its effect was to grant a one hundred per cent exemption for most employees; at the time he wrote it amounted to about a twenty-five per cent exemption. ${ }^{63}$ To eliminate this problem several states shifted from dollar to percentage exemptions. ${ }^{64}$ The latter type of exemption has the added advantage that its computation is simple and uniform, regardless of whether an employee is paid on a weekly, monthly, or other basis. When an exemption statute is framed wholly or partially in dollar amounts, extra computation, often involving an element of uncertainty, is required whenever the pay period is not identical to the period whicl the statute uses in formulating the exenption.

\section{General}

Features occurring in several state exemption statutes require additional comment.

As already noted some states, such as Michigan and Massachusetts, do not permit wage garnishments prior to judgment. This reflects a recognition that garnishment, with its possible serious consequences for the debtor, ${ }^{65}$ is less justifiable before the merits of the creditor's claim are estabhshed than once a judgment has been obtained.

In a number of states, among them Connecticut, Delaware, Illinois, Kansas, Louisiana, New York, and West Virginia, only one judgment

60 Compare N.Y. Civ. Prac. Laws \& Rules § 5231, with N.Y. Civ. Prac. Act \& 684. See also commentary following $\S 5231$.

61 E.g., Alaska, Connecticut, Georgia, Hawaii, Mllinois, Maine, Massachusetts, Michigan, New Mexico, North Dakota, Ohio, Oregon, Virginia, Vermont, and West Virginia. Compare Abrahams \& Feldman, supra note 58, at 157, 161, with Appendix A infra.

$62 \mathrm{KY}$. REv. StaT. \$§ 427.010(2), (3) (1962).

63 Note, Garnishment in Kentucky-Some Defects, 45 Kx. L.J. 322,329 (1956-57).

B4 Mlinois, Maryland (in part), Vermont, and West Virginia. Compare Abrahams \& Feldman, supra note 58, at 157, with Appendix A infra. Iowa, again contrary to trend, shifted the other way. See note 59 stspra. Exemptions generally remained unchanged in states specifying percentages except where the percentages are combined with dollar amounts. Colorado raised its flat percentage exemption from 60 to $70 \%$ (for heads of families; bachelors are required to get along on 35\%).

65 See text commencing at note 85 infra. 
creditor may levy against wages at one time.$^{68}$ Generally the first creditor who gets his papers to an officer is given priority until he is paid off; this seems desirable to minimize economic pressures from more than one creditor concurrently. Such provisions have been criticized from the point of view of collection agencies because one creditor with a substantial judgment can exclude all others for a long time. ${ }^{67}$

Provisions of the kind just mentioned are usually combined with others that have the effect of doing away with the need for repeated levies by the same creditor. Thus the New York and Louisiana statutes provide for installment payments by the employer. ${ }^{68}$ Other states make the initial execution levy a continuing one. ${ }^{69}$ Such a procedure greatly simplifies the garnishment process and reduces its expense. It eliminates the cost of multiple garnishments by a single creditor, at least as long as the debtor retains his employment. ${ }^{70}$ Further, it tends to assure other judgment creditors who have to wait their turn that the prior judgment is actually being paid off on a regular and rehable basis.

Some states give the courts far more flexibility in dealing with wage exemptions than does California. Thus in New York, what is there termed an "income execution" is obtainable without a court order, but is subject to judicial modification. ${ }^{71}$ The New York statute has been interpreted to permit courts to raise the exemption where garnishment of the nornal amount is "unduly burdensome" to the judgment debtor. ${ }^{72}$ In Connecticut an execution is subject to modification as the judge "deems reasonable"; 73 moreover, before any execution can be levied the court first orders the defendant to make reasonable payments in an amount set by the court. ${ }^{74}$

66 For illustrative provisions see Conn. GEN. STAT. REv. § 52-361 (Supp. 1964); D.C. Code ANv. § 16-572 (Supp. 1965); LA. Rev. Stat. tit. 13, § 3922 (1964); N.Y. Civ. Prac. LAws \& RULes $\S 5231(\mathrm{~h})$.

87 Hearings 36. A second criticism was that provisions of this kind put "a premium on time rather than negotiation. If you had such a restriction, each creditor would be prone, to act as rapidly as possible with a writ in lieu of negotiating or attempting a payment program .... ." Id. at 53.

68 LA. Rev. Stat. tit. 13, § 3923 (1964); N.Y. Civ. Prac. Laws \& Rules $\$$ 5231(a); (2).

69 E.g., Conn. GeN. Stat. Rev. § 52-361 (Supp. 1964); D.C. Code AnN. § 16-572 (Supp. 1965); IrI. Rev. StaTs. § 62-77 (1963).

70 As to who bears this cost see note 48 supra and text accompanying notes $45-49$ supra.

71 N.Y. Civ. Prac. Laws \& RULES \$\$ 5230, 5231 (g), 5240.

72 First Westchester Nat'I Bank v. Lewis, 42 Misc. 2d 1007, 249 N.Y.S. 2d 537 (Westchester County Court 1964); Seigel, Supplementary Practice Commentary following N.Y. Civ. Prac. Laws \& Rules \& 5231 (McKinney's Cons. 1964 Supp.).

73 Conn. Gen. Stat. Rev. \& 52-361 (f) (Supp. 1964).

74 Conn. Gen. Stat. Rev. § 52-361(a) (Supp. 1964). The court has great flesibility: "In fixing the amounts to be paid and the mauner of payment, the court or justice of the peace may take into consideration the circumstances of the defendant, including any other actions pending or judgments outstanding against him, the amount of the defendant's income and the amount of the claim or demand. Upon proof of change of circumstances of the 
If the defendant fails to make such payments, the creditor can then obtain an execution. ${ }^{75}$ Michigan provides a similar procedure: The defendant, at the time of judgment or later, may obtain an order permitting him to pay the judgment in installments, and the creditor cannot garnish as long as the defendant complies with the order. ${ }^{76}$

Not part of the exemption statutes, but closely related to them, are procedures in a few states, notably Ohio and Wisconsin, for the appointment of a trustee by the court at the request of the debtor, amortization through the trustee of the defendant's debts, and protection of the defendant from garnishments during the functioning of the trusteeship. ${ }^{77}$ In Ohio this procedure is available to any debtor facing garnishment. In some Ohio courts the clerk serves as trustee without compensation; in others the court appoints a suitable person who receives two per cent of the debtor's payments as full compensation. The debtor hists his creditors in the apphication and is required to pay only the nonexempt portion of his earnings to the trustee who distributes the money to the creditors. The creditors are required to accept the trusteeship; they are barred from garnishing wages as long as the debtor regularly pays the nonexempt portion. ${ }^{78}$

The Wisconsin procedure is of less help to debtors. Only debtors with incomes of 5,000 dollars a year or less may use it. ${ }^{70}$ The trustee must determine whether an amortization plan under which creditors will be paid off within two years is feasible, and creditors may object to any proposed plan. ${ }^{80}$ Thus in Wisconsin, unlike Ohio, a debtor who can only

defendant, any order for payments by the defendant may, at any time, be set aside or altered upon the motion of either party after notice and hearing."

75 Conn. Gen. Stat. Rev. § 52-361(b) (Supp. 1964). The court issues sucb execution ex parte. In New York, the income execution is first served on the defendant; if he defaults for 20 days it is served on the garnishee. N.Y. Crv. Prac. Laws \& RuLEs \$\$ 5231(c), (d). Siegel, note 72 supra, comments that the purpose is to enable "the judgment debtor to avoid embarrassment and possibly the more serious consequence of dismissal by making the $10 \%$ payments himself." Siegel further notes that only between $11 \%$ and $20 \%$ of judgment debtors have made the payments themselves, and questions whether the system should be continued. Compare OHIO REv. Code ANN. § 1911.40 (1953).

76 MTcr. Stax. ANs. §§ 27A.6201-27A.6251 (1962). This procedure apparently is not widely used except in Wayne County, Even there it is not very successful; in 195\%, more than $70 \%$ of partial payment orders were vacated because of nonpayment. FusFetD, op. cit. supra note 55 , at 17 .

77 Onto Rev. Code ANN. $\$ 2329.70,2329.71$ (Supp. 1964); Wrs. Stat. ANN. § 128.21 (1958).

78 OHIO REv. Code ANv. 82329.70 (Supp. 1964); Note, Garnishment of Wages in Ohio, 21 U. Cinc. L. Rev. 268 (1952).

70 WIs. STAT. ANN. \& 128.21(1) (1958).

80 Wrs. Stat. ANN. \& $128.21(3)$ (1958). The Wisconsin proceeding is part of a comprehensive system for the voluntary and involuntary administration of insolvent assets for the benefit of creditors. This system has been sustained against a elaim that it is in competition with and hence superseded by the federal bankruptcy law. In the Matter of Wisconsin Builders Snpply Co., 239 F.2d 649 (7th Cir. 1956), cert. den., 353 U.S. 985 (1957). 
afford to pay the nonexempt portion of his wages into the plan and who has many or large debts may not be able to avail himself of the procedure.

. The Ohio and Wisconsin statutes provide procedures that resemble the federal wage earners' plans ${ }^{81}$ and that may, particularly in Ohio, be simpler and less costly to use than the federal plan, as well as more readily accessible to the average debtor.

Exemption statutes often provide lower exemptions for single persons than for heads of families. California, in effect, makes such a differentiation. Bachelors need less money to live on, so the thinking apparently goes. This may be true, but the value of such a statutory distinction is doubtful, especially in states where the exemption is a percentage of earnings rather than a flat amount. The unmarried person will often be either young, starting his career and at a fairly low level of earnings, or divorced and making support payments. In either case, to maintain a minimum standard of hiving he is likely to need about as high a percentage of his earnings as a married person.

Some statutes also himit the exemption to residents, adding a complication of dubious value. There is substantial merit in having an exemption statute that is uniform in its operation and easily understood and administered. Illinois a few years ago clianged from a dollar exemption himited to heads of families to a percentage exemption applicable to everyone; the drafters took care to make clear the general applicability of the statute: "This exemption (and no other) applies irrespective of (1) the marital status of the employee, (2) the place where the compensation was earned or payable, and (3) the state where the employee resides." ${ }^{22}$ Other large states whose exemptions disregard marital status are Pennsylvama, Texas, New Jersey, and New York. ${ }^{83}$ By contrast, the Florida exemption applies only to resident heads of families, Ohio limits simgle men to one hundred dollars a month, and Michigan has an incredibly complicated scheme, uniquely its own, that distinguishes between householders and others, first and subsequent garmshments, and weekly and other pay periods. ${ }^{84}$

\section{II}

FORMULATING A WAGE GARNISHMENT POLICY

Should California continue to permit wage garnishments? If so, under what conditions? With what kind and amount of wage exemption? To

81 The so-called chapter 13 proceedings, 52 Stat. 93 (1938), as amended, 11 U.S.C. §§ 1001-86 (1964).

82 ILL. REV. STAT. § $62-73$ (1963). The change took place in two stages, the first occurring in 1959 and making the exemption uniform. IIl. Laws 1959, Garnishment Act $\S 6$, at 1959; Ill. Laws 1961, Wage Deduction Act, § 3, at 1470. For the pre-1959 law see Irx. REv. STAT. § 62-14 (1957).

83 See Appendix A infra.

84 Notes 187, 214, 201 infra. 
help formulate answers to these questions, this section of the study considers several factors that may be relevant when viewed together with the considerations already discussed.

\section{A. Adequacy of the Fifty Per Cent Exemption}

As noted, the California wage exemption is limited to fifty per cent in most cases. ${ }^{85}$ Such a low ceiling defeats the purpose of putting needed earnings beyond the reacl of process. "The basic theory of [the wage] ... exemption is that a debtor and his family, regardless of the debtor's improvidence, will maintain enougl money to retain a basic standard of living in order that the debtor may lave a fair chance to remain a productive meinber of the community."88

What is "a basic standard of living?" No hard and fast answer can be given, but it seems fairly clear that for the bulk of low-to-middle-income wage earners the exemption is grossly inadequate. The U.S. Department of Labor's family budget for an employee with a wife and two children is 6,859 dollars a year for a family living in San Francisco and 6,882 dollars for one in Los Angeles. ${ }^{87}$ This budget is designed to maintain a family at a "modest but adequate" standard of living. ${ }^{88}$ Even if one considers these figures ligh, recent average earnings $i$ the manufacturing industry were 130.47 dollars per week in San Francisco and 119.36 dollars in Los Angeles, ${ }^{89}$ or 6,784 dollars and 6,207 dollars a year, respectively.

Few would deny that a family with earnings in that range would need most of its incoine to maintain a living standard of some decency. Any sharp reduction $\dot{n}_{1}$ earnings, aside from causing immediate hardslip, is likely to acutely aggravate the debt problems of the family, bringing

85 See text following note 15 supra.

80 Perfection Paint Prod. v. Johnson, 164 Cal. App. $2 d$ 739, 741, 330 P.2d 829, 830 (1958). In Bailey v. Superior Court, 215 Cal. 548, 554, 11 P.2d 865, 867 (1932), the court said that "the underlying purpose of the statute exempting from execution certain property is to provide for the support and welfare of the family of the person claiming exemption." See also Holmes v. Marshall, 145 Cal. 777, 778-79, 79 Pac. 534, 535 (1905).

87 Information obtained by telephone from the United States Departinent of Labor, San Francisco office. Data applicable for March 1965 (adjusted for cost of living increase from 1959 budget); see Lamale \& Stotz, The Interim City Worker's Family Budget, MONTELY LABOR REv. 785, 787 (1960). The 1959 budget was approximately $\$ 6,300$ for the two cities.

88 Compare reference to Heller Committee budget of $\$ 7,088$ a year for a family of four, based on "a commonly accepted standard of living as the sum of those goods and services necessary to health and reasonably comfortable living. . . . On a weekly basis the annual budget is equal to about $\$ 136.00 . "$ Hearings 83 .

89 Information obtained by telephone from the United States Department of Labor, San Francisco office. Data applicable for March 1965; CacIforNIA Drv. of Labor Statistics and Research, Califformia Labor Statistics 18, 21 (Bull. No. 488-A, March 1965). For a more detailed study see U.S. Dept. of Labor, Occupational Wage Survex, Say FranciscoOAKLAND (Bull. No. 1430-37, Jan. 1965). 
action by other creditors and a chain reaction leading to family economic disaster. ${ }^{90}$ The costs of the low exemption to the debtor, his family, and the community (including other creditors) are high. While precise data are lacking, wage garnishment is probably predominantly used against debtors in the low-to-middle-income groups; "garnishee" is one word that is better known among the poor than among those who are economically well off.91

If the lowness of the exemption were the only serious problem posed by wage garnishments, it could be dealt with by increasing the exemption substantially. Unfortunately there are other related problems not capable of such simple solution. These are considered next.

\section{B. Garnishment and Employment}

It is hardly news that an employee who gets his wages garnished runs a serious risk of being fired-at least if he permits it to happen repeatedly. The employee's fear of discharge collects at least as much nioney for creditors as actual levies; it may well collect more. ${ }^{92}$

One observer, who worked in the personnel department of several plants, reports that in every case the company set a hmit on the number of garnishments that it would tolerate within a given period as to any employee; some companies regard a single garnishment as grounds for discharge. He notes that "it is detested as an unmitigated nuisance by employers to such an extent that even union contracts tacitly or specifically recognize the right of an employer to discharge an employee whose debts result in more than a prescribed number of garnishments within a specified period."

While collection agencies tend to minimize the problem of discharges, ${ }^{94}$ they recognize that the threat of garnishment "collects an awful lot of

90 For illustrative case studies see CENTER FOR CONSUMARR AFraIRs, UNIVERSITY OF WISconsin, UnIVersity Extenston, The Spender Syndrome [hereinafter cited as Spender Syndrome], cases $1,6,9,19,21,31,37,44,48,51,65,67$ (1965). Some of the families involved in that study had to receive welfare grants because of garnishments. Id. at cases $9,37,44$.

For data as to the substantial proportion of income which is used for repaying consumer credit, see text commencing with note 160 infra.

91 Caplowitz, The Poor Pay More 21 n.7 (1963). Credit merchants sell to the poor as well as to higher income groups (though they may not be the same merchants). The proportion of low income families with consumer installment debt is about the same as the national average. Id. at 101. Most poor persons use credit for some major purchases. Id. at 100.

92 See Conard, An Appraisal of Illinois Law on the Enforcement of Judgments, 1951 J. of IrI. L.F. 96, 100. The article is written from a viewpoint favorable to creditors.

93 Note, Garnishment in Kentucky-Some Defects, 45 KY. L.J. 322, 330 (1956-57). The article is written from a point of view favorable to debtors. See also Note, State Wage Exemption Laws and the New Iowa Statute-A Comparative Analysis, 43 IowA L. REv. 555,557 (1958).

${ }^{94}$ See Hearings 56-57. 
money. ${ }^{205}$ At a recent California legislative hearing, one California legislator gave his experience:

I know that there are companies that have inflexible rules if they have so many attachments. They are discharged regardless of whether they are valuable employees or not. . . . Now this is my own experience so I know what I am talking about in this respect, and you may be right that it is only a small percentage, but this is very important to these people who lose their jobs because of attachments. I've seen it done time and again and many of these people, you know we might as well admit it, they maybe don't go to their lawyer, if they do go they haven't any money to pay him. ${ }^{96}$

He said that "most of the compamies have a rule, sometimes only one and a maximum of three [garnishments] and they lose their job."07 Other legislators also expressed their concern. ${ }^{98}$ The then research director of the California Labor Federation, Don Vial, gave numerous examples of discharges resulting from garnishments. ${ }^{90}$ The resulting hardship can be acute, as illustrated in a letter to Vial by a former Dow Chemical Company employee, an agricultural research assistant who was earning $\$ 5,000$ a year. Marital and child custody problems required the employee to seek extensions of time to pay his bills, and one creditor, after four months' delinquency, turned the debt over to a collection agency. What happened next is graphically described by the ex-employee:

They, (the collecting agency) immediately wrote my employer. They, (the Dow Chemical Company) told me that if the creditor attached, they would have to let me go. I went and talked to the people at the collection agency and explained this situation. They demanded half the amount which was $\$ 125.00$ and I said I did not even have $\$ 5.00$, and they said they would attach my wages. I reasoned that they wouldn't because they could only get so much money and they knew I would get fired. Well, they attached and they got $\$ 80.00$ or $\$ 90.00$ and I got fired. Since last April I have not been able to get any kind of job in my field because they all checked and Dow says I was fired because of a wage attachment and the prospective employer treats ine like I had ten tails and I think it is a stinking mess. ${ }^{100}$

Nor is this an isolated case. A number of union officials wrote of job losses by their members as a consequence of wage garnishments, "of the lopelessness of the situation many members found themselves in,"

95 Id. at 29 (testimony of Kenneth MrGilvray, legislative counsel for Associated Credit Bureaus of California).

96 Id. at 59 (remarks of Assemblyman Harvey Johnson).

ot Id. at 18-19; see id. at 71 .

98 E.g., coniments of Asseniblyman Milton Marks, id. at 7, 8.

99 Id. at 62-64.

100 Id. at 63 . 
and of "extreme hardship."101 Vial summed up the paradoxical effect of wage garnishments by noting that while preservation of the debtor's ability to pay is important in order to have debts paid, garnishmentinduced discharges destroy ability to pay. The fear of discharge, Vial added, "is a real factor that causes a debtor to take the course of bankruptcy which may be the less offensive alternative to him but the worst from a public policy point of view."'102

Thus, garnisliment of wages poses problems not only of actual loss of employment, but of threatened loss with its attendant temptation to use bankruptcy as a way out (discussed in detail below). Aside from bankruptcy, the question remains whether society should consider the threat of loss of employment as a legitimate debt-collecting device. We have given up imprisonment for debt; do we want to tolerate joblessness for debt?

Short of abolishing wage garnishments, the possibilities for dealing with the employment problem are principally: (1) to attempt to prohibit discliarges based on garnishment; (2) to utilize a trusteeship procedure, such as the Ohio one, which gives an employee protection against garnishments and at the same time provides for amortized payment of his debts; or (3)-possibly in conjunction with (2) - to increase the exemption and modify the garnishment procedure.

Discussing these in inverse order, the third alternative is likely to have an ameliorative effect on discharges to the extent that it decreases the use of wage garnishments. Yet in New York, whose garnishment law is relatively favorable to debtors, garnishnents apparently still lead to discharges: Several bills were introduced in the 1965 session of the New York legislature designed to prohibit firings based on that ground. ${ }^{103}$ This is not to suggest, however, that such an approach may not reduce the problein.

Trusteeship would benefit employees who can avail themselves of legal services and arrange for regular payment to the trustee of the nonexempt part of their wages. Essential to the success of any such procedure would be the enthusiastic co-operation of the courts and a very low (if any) deduction from payments for administrative costs. Society now handsomely subsidizes the garnishment process; ${ }^{104}$ the subsidy could well be shifted to trusteeships. The success of this kind of trusteeship in California is obviously uncertain. By itself, it is probably of limited value;

$101 \mathrm{Id}$. at 64 . For case studies see SpENDER Syndrome passim.

102 Hearings 62.

103 Senate Intro. 2168 (1965); Senate Intro. 2299 (1965); Senate Intro. 3061, Assembly Intro. 4920, vetoed July 19, 1965; Senate Intro. 4146 (1965); Senate Intro. 4164, Assembly Intro. 3577 (1965).

104 See note 48 supra. 
bankruptcy rates in Ohio and Wisconsin are not very different from those in California. ${ }^{105}$

The most straightforward way would be to provide that an employee shall not be discharged because of wage garnishments. This was, in essence, the approach of the New York bills. ${ }^{10 e}$ The question that immediately arises is how such a law would be enforced. What about the employer who dislikes garnisliments and looks for-and finds-other reasons to discharge the employee whose wages are "hit"?107 These obstacles are real but not insuperable. First, as to the problem of deciding whether an employee was "really" discharged because of garnishments or for some other reason, the National Labor Relations Board and the United States courts of appeals have for over a quarter of a century applied a provision of the Labor-Management Relations Act $^{108}$ that poses an analogous problem. Under that act an employer may discharge an employee for any reason, even for no reason, as long as he doesn't do it because of the employee's union membership or activities. ${ }^{100}$ The Labor Board and the courts frequently resolve the issue of whether an employee was discharged because he belonged to (or was active in) a union or because of other

105 If trusteeship were an effective tool against threatened loss of employment due to wage garnishments, then one would anticipate lower individual bankruptcy rates to the extent that debtors no longer need to turn to bankruptcy to safeguard their job. The measure is obviously imprecise. The following data are taken from the BankRuPTCY STUDY CoNar., AMIERICAN Collectors Ass'N, ANNuAL REPORT 14-15 (1963-64) [hereinafter cited as ACA BanzRUPtcy Study Comar.].

\begin{tabular}{lcc}
\hline State & $\begin{array}{c}\text { No. of families } \\
\text { for each individual } \\
\text { bankruptcy-1950 }\end{array}$ & Same-1960 \\
\hline California & 975 & 175 \\
Ohio & 678 & 200 \\
Wisconsin & 1446 & 104 \\
\hline All U.S. & 1504 & 377 \\
\hline
\end{tabular}

See also Table 2 accompanying note 123 infra.

108 Thus, Senate Intro. 2168 would have amended the N.Y. labor law to make such discharges an unfair labor practice. Senate Intros. 2299, 3061 and 4164 would have amended the provisions with income executions to provide that "it shall be unlawful for an employer to discharge an employee against whom an income execution ... . is served ... solely because of such service ...." Two of these bills further made such a discharge a misdemeanor. Senate Intro. 4146 also would have prohibited discharge. It added the interesting provision that an employer would remain liable on the income execution-on the continuing garnishment -as though he had not discharged the employee. The approach of Senate Intro. 2168 is not available in California because it does not have a labor law that specifies unfair labor practices.

107 See Hearings 8.

10861 Stat. 136 (1947), as amended, 29 U.S.C. $\$ \S 141-87$ (1964).

10961 Stat. 140 (1947), as ainended, 29 U.S.C. $\$ \S 158$ (a) (1), 158 (a) (3) (1964). 
reasons. Presumably, whether the discharge was for garnishments is also capable of determination. However, resolution of discharge problems under the Labor-Managenient Relations Act often involves complex and protracted hearings. It nuay well be doubted whether employers should be subjected to the expense of extended trials dealing with alleged garnishment discharges. It may be doubted, too, low many employees could, as a practical matter, avail themselves of the benefits of such a law.

The employee would have to turn to the courts; California has no counterpart of the NLRB. A law of this type would not, in all likelihood, be effectively enforced through criminal sanctions; district attorneys, already burdened with nore pressing matters, would be less than eager to initiate prosecutions, particularly against respected companies. The individual employee could not afford the expenses of litigation, which would be several hundred dollars for the simplest case and could easily be many timies that aniount. However, a substantial number of enployees might be aided by their unions; when the union carries the ball on behalf of a discliarged niember, judicial resolution would become feasible. Under some collective bargaining agreenients the issue could also be submitted to arbitration, which would provide a speedier and less expensive determination.

Quite apart from the difficulties of hitigation, employers might well object that their right to discliarge for garnislıments should not be impaired: Not only does the processing of garnishments entail extra work and expense for the employers, but, the argument runs, they have a legitimate interest in the financial responsibility of their employees-an employee in deep financial trouble niay not be a very productive one. There is merit in such contentions, althougl they are not necessarily decisive. A family's financial crisis may have widespread effects: effects on the creditors, effects on the legal machinery of society, effects often enough in terms of uneniployment insurance, welfare payments, personal tensions, and even family break-up..$^{110}$ Employers are not automatically entitled to be exenipt from these effects.

In fact, a no-discharge-for-garnishments rule could well have the healthy effect of encouraging more employers to take an active interest in the debt problems of their employees. The wise use of credit is a complex skill that has to be learned; employers-at least large onescan do a great deal by way of providing information and counseling, as well as assistance through avenues such as credit unions. Some of this, of course, is being done already.

$110 \mathrm{It}$ is not suggested here that garnishments are the principal cause of financial crisis, but they commonly are the precipitating event. 


\section{Garnishment and Bankruptcy}

I'm not one to run up my bills nor am I one to say a man should not have to pay his bills. Wage attachments forced me to declare bankruptcy and almost cost me my job. Once, there wasn't a week passed that my check wasn't attached.111

My wages were attached twice in 1959 against debts incurred in a previous marriage. I had remarried and my wife was pregnant and so to protect my job I was forced to file bankruptcy. . . . My total mdebtedness amounted to $\$ 2,000$, and I would have gladly paid it off given a decent chance and with no threat to my job. ${ }^{112}$

These statements illustrate a serious effect of wage garnishments. An employee who is threatened with discharge as a result of a garnishment often turns to bankruptcy as his last resort. Attorneys doing bankruptcy work are abundantly familiar with the situation of a client who first walks in, garnishment papers in hand, and announces: "My boss says: 'One more of these and I'm through.' I guess I better file bankrupt." In the words of one such attorney, who is also a legislator: "I am connected with an office that handled a few bankruptcies, and I'd say $95 \%$ are for the purpose of saving their jobs, and the employers, I think, have a rule of two or possibly three attaclıments within twelve months then they lose their jobs."113

Garnishment is not the only factor that contributes to bankruptcies, but even collection agencies agree that they often trigger bankruptcies whatever the underlying causes may be. ${ }^{114}$ And bankruptcies are rising with dizzying speed. In California the number of bankruptcy petitions increased from 4,124 during the year ending June 30, 1950, to 19,404 in

111 Hearings 63.

$112 I d$. at 64 . For other graphic illustrations see Spender Syndrome cases 1, 6, 9, 31, 48, 51. Recent studies of personal bankruptcies in Michigan and Arizona indicate a substantial concentration of bankruptcies among married blue collar workers, with children, and with an income between $\$ 3,000$ and $\$ 6,000$ a year. See, Personal Bankruptcy a Class Problem, 19 Personal Fiv. L.Q. 111 (1965); Consumer Bankruptcies, Furance Facts (Monthly newsletter of the National Consumer Finance Association, June 1965).

113 Hearings 71 (remarks of Assemblyman Harvey Johnson). The interchange immediately following this statement between Assemblyman Johnson and Mr. Vial brought out that collective bargaining agreements do not protect employees against discharges based on garnishments, because "the employer does not want to negotiate on this type of an issue." Id. at 71. If the union "tried to make this a collective bargaining issue they would not likely succeed because it does not involve working conditions specifically. . . . I am not saying that I agree with this. I am saying that it is very difficult to negotiate in this area." Id. at 72. The NLRB does not protect against this kind of discharge unless it is motivated by a desire to discriminate against a union adherent. E.g., Michigan Lumber Fabricators, Inc., 111 N.L.R.B. 579 (1955); Bardon of Hollywood, 48 N.L.R.B. 1055 (1943); Chambers Corp., 21 NL.R.B. 808 (1940). Compare Campbell Coal Co., 112 N.I.R.B. 941 (1955).

114 Hearings 21. 
1960 and 29,651 in 1964-an increase of over fifty per cent in the past five years alone and of over six hundred per cent during the fifteen-year period. ${ }^{115}$ More than ninety per cent of these were nonbusiness bankruptcies in 1964: They were filed by individuals and families whose personal debts had become too much for themn. ${ }^{116}$ If the overall increase in bankruptcies has been rapid, personal bankruptcies have been rising even faster, both in California and throughout the country. ${ }^{117}$

Today one out of every six persons who files bankruptcy does so in California. ${ }^{118}$ Why is bankruptcy a matter of concern? First, as Myers notes: "The bankruptcy problem is important because of the human distress it represents. Although uminformed people may minimize the gravity of the consumer bankruptcy problen by saying that only onetenth of one per cent of the population goes bankrupt, there is a qualitative dimension in hunian distress that is understated by such statistics." 110

Secondly, losses from nonbusiness bankruptcies now exceed one billion dollars a year nationally. ${ }^{120}$ Wage garnishments that precipitate bankruptcy hurt not only the debtor and his family but a good many creditors as well.

The extent to which wage garnishments contribute to bankruptcy cannot be measured precisely. We do not know in how many individual bankruptcies a garmshment was the last straw. Even if we knew, we could not tell how many such bankruptcies would have happened sooner or later in any event. We are not entirely without data: We know the number of bankruptcies on a state-by-state basis and we know the garnishment laws of the states. Any comparison between them must be treated with great

1151950 Director of the AdMmistrattve OfFice of the United States Courts, Annuar Reports [hereinafter cited Annual Report] Table F-2; 1960 Id. at Table F-2; 1964 Id. at Table F-2. California is not alone. Between 1947 and 1963, nonbusiness bankruptcies in the U.S. increased $1260 \%$ while the population grew $31.3 \%$. Myers, Non-Business Bankruptcies, in Proceedings of Tenth Annual Conference, Council on Consumar InforMaTion 2. They nearly quadrupled in the decade 1953-62. See also Countryman, The Bankruptcy Boom, 77 HARv. L. REv. 1452 (1964).

1101964 AnNuar RePORT Table F-3. Of the 29,651 bankruptcy petitions filed in California in $1964,26,980$ or $91 \%$ were personal bankruptcies. The figures for nonbusiness or personal bankruptcies used throughout are the sum of the voluntary "employee" and "other non-business" bankruptcy filings shown in Table F-3.

117 In California, personal bankruptcies rose from 17,265 in 1960 to 26,980 in 1964, up $56 \%$. All other bankruptcy filings rose from 2,139 to 2,671 , up $25 \%$. The U.S. figures for the same years are: personal bankruptcies-97,742 and 155,193, up 59\%; all other bankruptcies-12,292 and 16,526, up 34\%. 1960 ANNOAL RePORT Tables F-2, F-3; 1964 Id. at Tables F-2, F-3.

118 Durnig the year ending June $30,1964,26,980$ nonbusiness bankruptcy petitions were filed in California, 155,193 in the U.S. Note 117 supra.

119 Myers, supra note 115, at 9. Myers argues that bankruptcy is at least as important as many medical and social problems whose per capita incidence is no higher and toward whose solution we contribute generously.

120 Id. at 9-10; Countryman, supra note 115, at 1456. 
caution: A correlation does not necessarily mean' a cause and effect relationship. Garnishment laws may not be the only relevant factor with respect to which one state differs from another. Further, bankruptcies have been rising in all states, even those that do not permit wage garnishments. ${ }^{121}$

There is a consensus among referees and students of bankruptcy problems that the number of individual bankruptcies in a state is significantly affected by the leniency or harshness of its garnishment laws. ${ }^{122}$ Subject to the himitations mentioned, the available data suggest that the consensus may be correct.

The states with the lowest per capita bankruptcy filings are mamly those that either prohibit wage garnishments or severely restrict their use. The highest filings in relation to population tend to occur in states where the garnishment remedy is freely available to creditors. The following table illustrates the point and shows dramatic differences in bankruptcy rates.

TABLE 2

States Havang the Highest and Lowest per Capita

BANKRUPTCY RATES, 1962123

\begin{tabular}{lclc}
\hline State & $\begin{array}{c}\text { No. of Filings } \\
\text { per 100,000 } \\
\text { population }\end{array}$ & \multicolumn{1}{c}{ State } & $\begin{array}{c}\text { No. of Filings } \\
\text { per 100,000 } \\
\text { population }\end{array}$ \\
\hline Alabama & 279 & North Carolina & 1 \\
Oregon & 200 & Texas & 2 \\
Tennessee & 184 & South Carolina & 3 \\
Maine & 153 & Pennsylvania & 4 \\
Georgia & 149 & Maryland & 5 \\
Arizona & 147 & Florida & 7 \\
California & 145 & Delaware & 10 \\
Mllinois & 134 & South Dakota & 11 \\
Ohio & 132 & New Jersey & 12 \\
Colorado & 131 & Alaska and the & \\
& & District of Columbia & 13 \\
& & United States as a whole: 72 & \\
\hline
\end{tabular}

Of the states in the high group only Illinois has an exemption as high as eighty-five per cent; it went into effect in 1961 and its apparent

121 ACA Bankruptcy Study Comar. 16-17.

122 Myers, supra note 115, at 11; Snedecor, Consumer Credit and Bankruptcy, 35 REP. J. 2 (1961). The annual report of the Bankruptcy Study Committee of the American Collectors Association, note 105 supra, recognizes the existence of such a consensus but dissents from it. At the same time it states that "the per capita [bankruptcy] filings in a given state partially reflect the strength of collection laws in given states" and that "strengthening collection laws in many states would increase [bankruptcy] filings." ACA BANERUPTCY StuDY Comax. 25.

123 Myers, supra note 115, at 5. See also Hearings App. B. 
consequences will be discussed below. The states in the low group all had very high or one hundred per cent exemptions, except Maryland and in that state the use of garnishment is limited. ${ }^{124}$

Illinois raised its exemption from forty-five dollars a week to eightyfive per cent in 1961. ${ }^{125}$ Between 1961 and 1964, the number of nonbusiness bankruptcies filed in Illinois declined nine per cent; nationally during the same period they rose eighteen per cent. ${ }^{128}$ The substantial change in exemption, one nray infer, contributed to the stemming of the bankruptcy tide. As might be anticipated, the reduction in personal bankruptcies has not been overwhelming. As long as garnishnients continue so will the threat of losing employment and the impulse to meet the threat by fleenig toward bankruptcy.

Iowa nloved in the opposite direction. In 1957 it abohished its one hundred per cent wage exemption and substituted an inadequate exemption of thirty-five dollars a week plus three dollars per dependent. ${ }^{127}$ Only 431 bankruptcy petitions of all kinds were filed in Iowa during the year ending June $30,1957 .{ }^{128}$ Since then bankruptcies in that state have been growing at a pace that is astonishing even for bankruptcy figures. Iowa bankruptcies more than quadrupled between 1957 and 1963, almost double the national rate. ${ }^{129}$ During the same period California filings went from 11,629 to $27,068 . .^{130}$ An increase at Iowa's rate would have brought Cahifornia to over 44,000 . Considering that California experi-

124 In Maryland a creditor can only garnish wages "actually due at the date of the attachment ...." Mo. ANN. CodE art. 9, § 31 (Supp. 1965).

125 Note 82 supra.

120 The year-by-year figures, as compiled from Tables F-3 of the Annual Reports of the Director of the Administrative Office of the United States Courts for the years 1961-1964 are:

\begin{tabular}{ccc}
\hline Year & Illinois & U.S. \\
\hline 1961 & 16,356 & 131,397 \\
1962 & 13,705 & 132,118 \\
1963 & 14,057 & 139,176 \\
1964 & 14,900 & 155,193 \\
\hline
\end{tabular}

Bankruptcies have been rising in Illinois since 1962, but at a much slower rate than in the country as a whole. The ratio of Illinois nonbusiness bankruptcies to U.S. nonbusiness bankruptcies has declined steadily: $12.4 \%$ in $1961,10.4 \%$ in $1962,10.1 \%$ in 1963 and $9.6 \%$ in 1964.

127 See Note, State Wage Exemption Laws and the New Iowa Statute-a Comparative Analysis, 43 Iowa L. REv. 555, 560 (1958).

1281957 ANNUAL REPORT Table F-2. The report does not include nonbusiness bankruptcies; hence in the discussion of Iowa, total filings are used throughout.

129 Iowa filings were 431 in 1957,922 in 1960,1734 in 1963; U.S. filings were 73,761, 110,034, and 155,493 in the same respective years. 1957 ANNOAL REPORT Table F-2; 1960 Id. at Table F-2; 1963 Id. at Table F-3.

180 Ibid. 
enced a rapid population expansion during these years, the difference is striking.

It might be objected that Iowa has so few bankruptcies that a small numerical rise produces a big percentage increase and that this limits the validity of the comparison. To test this objection, Iowa might be compared with another state having few bankruptcies. Nebraska in 1957 had the same number as Iowa-431. Nebraska's increased to 953 in 1963 , a "growth rate" close to that of the country as a whole and far below Iowa's. ${ }^{131}$

California has a per capita rate of personal bankruptcies more than five times as higl as $\mathrm{New}$ York. ${ }^{132}$ That again does not prove that garnishment laws account for the difference, but what does? It has been suggested by a collection agency spokesman that the large number of newcomers to the state contribute to the difference. ${ }^{133}$ This does not rule out the role of garnishments, even if it is assumed that many of the bankrupts are recent arrivals who rush too enthusiastically to buy all the things they regard as necessary for the California way of life, or who meet economic disappointment. Recognizing that overextension of credit-to newcomers or oldtimers-may well be a key factor underlying bankruptcy, it is garnisliments that often push the debtor over the edge.

Even collection agencies grant that without wage garnisliments there would be fewer personal bankruptcies. They argue that this would be because then there would be no way to compel a debtor to pay his .debts. ${ }^{134}$ This contention raises the important question of the need for wage garnishments as a collection device, the question considered next.

131 Nebraska filings were 431 in 1957, 511 in 1960, and 953 in 1963. Ibid. The foregoing data may be summarized as follows: Between 1957 and 1963 banliruptcy filing in the United States as a whole increased $111 \%$, in Nebraska $121 \%$, in California $132 \%$ and in Iowa $302 \%$. 132 During the year ending June 30, 1964, New York had 5033 nonbusiness bankruptcy filings, Cahifornia 29,651. 1964 Anwoar REPORT Table F-3.

133 Hearings 35 (testimony of Joseph L. Weissman, Counsel for the California Association of Collectors).

134 ACA BANkrUptCy STUdy CoMac. 22: "Bankruptcy rates are low in states like Texas and Florida only because there is no necessity for the debtor to file since the laws are so lax he cannot be put to more than slight inconvenience and never be legally forced to pay anyway." The "lax" laws are the $100 \%$ wage exemptions granted by Texas and Florida. The quoted statement is particularly enlightening in view of the publication's contention that a state's garnishment laws have nothing to do with the bankruptcy rate. See also Hearings 13: Raising the exemption "may lower the number of filings because there would be no reason to take bankruptcy if they cannot be forced to pay anyway. The number of bankruptcy filings would no doubt decrease in those states where garnishment laws were relaxed, but the number of people not paying their bills would actually increase." (testimony of Robert C. Kopriva, Legislative Chairman, Associated Credit Bureaus of California, quoting from an article by David Earl in the Collectogram, September 1963-the official bulletin of the Oregon Collectors Association). 


\section{Need for Wage Garnishments}

The extensive use of wage levies in California has already been indicated. ${ }^{135}$ It is further illustrated by an examination by the author of a sample of cases filed in the San Francisco Municipal Court. The examination consisted of reviewing the action files of one hundred cases commenced in January $1964 .{ }^{136}$ The date was selected as one reasonably likely to reflect current practices but sufficiently remote to provide fairly complete garnishment data. ${ }^{137}$ Municipal court actions were chosen because garnishments are most commonly and typically used in those actions. ${ }^{138}$

Thirty-one of these cases resulted in levies of writs of attachment or execution; there were a total of sixty-eight sucl levies. Of them at least forty-seven, in fifteen actions, were wage levies. ${ }^{139}$ Garnishment is particularly common after judgment-four out of five execution levies were made against wages. Far and away the most frequent users of wage garmishments are collection agencies.

How effective are wage levies as a collection device? While a review of the case files shows what each levy caught, this does not give an accurate picture of their effectiveness. A garmshment may induce a defendant to pay off a debt or make payments on account; such payments are not always reflected in the files. The survey showed that wage levies caught something at least once in eleven of the fifteen cases in which they were used. About half the execution levies on wages were successful in that sense; they collected about one quarter of the principal indebtedness in the actions in which they were used. ${ }^{140}$ In two of the actions the files show that wage levies satisfied the judgments in full.

Purchases on credit by consumers and hospital or medical bills are the main sources of suits that give rise to wage garnishments. ${ }^{141}$ This

135 Text accompanying note 1 supra.

136 San Francisco Munic. Ct. Action Nos. 27,363-27,462.

137 The examination was made in April 1965.

138 The Mumicipal Court jurisdiction extends to "all cases at law in which the demand, exclusive of interest . . . amounts to five thousand dollars $(\$ 5,000)$ or less . . ." CAL. CodE Crv. Proc. $\S 89$ (1) (a). Small claims court jurisdiction extends to actions up to $\$ 200$. CaI. CODE Crv. Proc. \$ 117. Actions claiming $\$ 200$ or less may be brought in either court. However, assignees-collection agencies-niay not sue in small claims court. CAL. CoDE CIV. Proc. \& 117f. Section 117 ha provides: "No attachment or garnishment shall issue from the small claims court, but execution may issue ...."

130 See Appendix B infra. In a few instances the files did not disclose whether the levies were on wages or other property.

140 By contrast, four out of five bank levies were successful, producing sufficient money to pay off two-thirds of the principal indebtedness in all cases where execution was levied on bank accounts.

141 The author's survey disclosed that $60 \%$ of the garnishment-producing debts resulted 
leads to the contention of collection agencies that garmishments are essential to the economy. Current earnings, they argue, are often the only asset that a debtor has and that a creditor can reach. Without garnishment, the argument continues, fewer debts would be collected. This in turn, it is claimed, would lead to a tremendous drop in the granting of consumer credit, thus adversely affecting the economy as well as those families to whom credit would no longer be available. ${ }^{142}$ A spokesman for collection agencies illustrated his viewpoint by arguing that it is much harder for a person to buy on credit in New York than it is in California. ${ }^{143}$

These contentions are important, if correct. However, estimates made by the collection agencies and other available data indicate that consumer credit is as readily available in New York as in California and that the extension of consunier credit is unrelated to garnishment laws. Data given a California legislative committee by the Associated Credit Bureaus of California show that in $1963,6.621$ billion dollars of installment credit was extended in Califorma and 6.124 billion dollars in New York. ${ }^{144}$ This amounts to 24.6 per cent of total retail sales in California during 1963 and 25.5 per cent of New York sales. ${ }^{145}$ The Associated Credit Bureaus also covered five other states: Colorado, Texas, Florida, North Carolina, and Alabama. The ratio of installment credit to retail sales varies very little among them or, for that matter, from the ratio in New York or Califorma. ${ }^{140}$ This is particularly interesting because Texas,

from purchases, $26.7 \%$ from hospital and medical services, $6.7 \%$ from loans and $6.7 \%$ from rent. Purchases included a used car, furniture, jewelry, clothing, and several items merely listed as "goods, wares and merchandise"-a catchall designation often used in complaints.

142 Hearings 29-30, 37-38.

143 Id. at 37 .

144 Id. at App. A (letter from Robert C. Kopriva, Legislative Chairnan, Associated Credit Bureaus of California). These are unofificial estimates; there appear to be no ofícial data showing retail installment credit by states. See also note 148 infra.

145 In dollars the respective retail sales figures are $\$ 26.889$ billion and $\$ 23.977$ billion. Bureau of the Census, Census of Bustness, 1963 Retatu Trade, Cảhfornia 6-5 (1965); Id. at New York 34-5. The percentages given in the Kopriva letter, note 144 sispra, are incorrectly identified as showing installment credit as a percentage of retail sales. Rather, the letter shows the ratio of installment credit in California and New York to all such credit extended in the U.S. in 1963. (California's was $10.9 \%$ of the national total; New York's, $10.1 \%$.) In 1963, California and New York were also close in personal income, $\$ 52.419$ billion and $\$ 53.120$ billion, respectively; per capita personal income was $\$ 2,980$ in Califorma and $\$ 3,000$ in New York. U.S. Dep'T of CoManerce, Survex of CurRent Business 13 (April 1964).

146 The data for the seven states are as follows: (installment credit data from Kopriva letter, note 144 supra; retail sales figures from CENsus of Busness, 1963, note 145 supra 
Florida, and North Carolina exempt the entire earnings of a family from garmishment, while wage garnishment is freely available in Colorado and Alabama.

In short, the correlation of installment credit to retail sales does not appear to vary in accordance with garnishment laws. ${ }^{147}$ Nor is the volume of retail sales or installment credit lower in states that do not permit garnishments, at least when measured against personal incone; ${ }^{148}$ again there is no correlation to garnishment laws. ${ }^{149}$ Finally, it bears noting that per capita personal income does not vary in accordance with whether a state has tough or lement garnishment laws-precisely the opposite of what might be expected if contentions that abohtion of wage garnish-

at Alabama 2-5, California 6-5, Colorado 7-5, Florida 11-5, New York 34-5, North Carolina 35-5, Texas 45-5).

\begin{tabular}{lccc}
\hline State & $\begin{array}{c}\text { Installment Credit } \\
\text { Extended in } 1963\end{array}$ & $\begin{array}{c}\text { Retail Sales } \\
\text { in 1963 }\end{array}$ & $\begin{array}{c}\text { Ratio of } \\
\text { Installment } \\
\text { Credit to } \\
\text { Retail Sales }\end{array}$ \\
\hline Alabama & \multicolumn{2}{c}{ (In billion dollars) } & \\
California & 0.794 & 3.253 & 24.4 \\
Colorado & 6.621 & 26.889 & 24.6 \\
Florida & 0.665 & 2.649 & 25.1 \\
New York & 1.905 & 7.610 & 25.0 \\
North Carolina & 6.124 & 23.977 & 25.5 \\
Texas & 1.212 & 4.975 & 24.4 \\
\hline
\end{tabular}

147 This is corroborated by comparing retail sales and outstanding bank consumer credit (including consumer paper bought by banks) in the ten most populous states for 1964. The ratio is $19.9 \%$ in New York, $17.1 \%$ in Pennsylvamia, $14 \%$ in California, and between 13 and 15.2\% in Florida, Illinois, Massachusetts, Michigan, New Jersey, Ohio, and Texas. U.S. Dep't of Comanerce, Montelex Retall Trade 9-11 (March 16, 1965). Data on bank consumer credit outstanding on June 30, 1964, by state, supphed by Federal Reserve Bank of San Francisco in a letter to author, April 20, 1965, includes bank automobile loans (plus automobile paper purchased from dealers), installment loans for purchases of other retail consumer goods (including paper bought by banks), repair and modernization loans for residences, and loans for miscellaneous personal expenditures.

148 Total personal income in the states listed in note 146 was as follows in 1963 (in billion dollars): Alabama-5.542, California-52.419, Colorado-4.678, Florida-11.933, New York-53.120, North Carolina-8.630, Texas-21.118. SuRvey or Current BusINess, op. cit. supra note 145, at 13 .

149 Thus, the ratio of installment credit to total personal income is $14.3 \%$ in Alabama, $12.6 \%$ in California, $14.2 \%$ in Colorado, $16.0 \%$ in Florida, $11.5 \%$ in New York, $14.0 \%$ in North Carolina and $15.3 \%$ in Texas. The ratio of retail sales to total personal income is between $56 \%$ and $60 \%$ in Alabama, Colorado, Florida, North Carolina and Texas, and again lower in both New York and California. Ratios are computed from data in notes 146 and 148 supra. 
ments would seriously harm the economy of the state were true. ${ }^{150}$ For example, the Southeastern states all have per capita incomes well below the national average regardless of what their garnishment laws are. Among them Florida, which does not allow wage garnishments, happens to rank highest, while Mississippi, which not only allows them but has a low exemption, ranks lowest. ${ }^{151}$ And each of the following pairs of states has nearly the same per capita income, but radically different garnishment laws: California and New York, Pennsylvania and Ohio, Washington and Hawaii, Vermont and Florida. ${ }^{152}$

There is some evidence to back one contention made by collection agencies. The percentage of recovery on accounts assigned to them tends to be lower in states where wage garnishments cannot be freely used. ${ }^{153}$ But it is higher in New York than in California, and the correlation is far from perfect. ${ }^{154}$ The same data strongly suggest that an exemption as high as ninety per cent would not interfere with recoveries, for not only New York but New Jersey and Nebraska have a higher percentage of recoveries than California. ${ }^{155}$

In any event, variations in collection agency recovery rates have no observable influence on the extension of consumer credit. There is no evidence to support a claim that wage garnishnent laws contribute to the extension of credit, to the volume of retail trade, or to the level of per capita income. One probable reason for this is that wage garnishment is only one tool in a creditor's kit. It is a full kit, including prelitigation collection procedures, skip tracing, repossession of articles sold (a particularly powerful weapon for many credit sellers), attachment and execution levies against cars, bank accounts, and honies, liens of various

I50 SURVEY OF CURRENT BUSINESS, op. cit. supra note 145, at 13.

151 Ibid. Florida per capita income is $86 \%$ of the national average, Mississippi $56 \%$. North Carolina (which has a $100 \%$ wage exemption) is $74 \%$-the exact average of the Southeastern states. A state's relative prosperity obviously hinges on many factors; what the per capita income figures show is only that there is no observable relation between a state's prosperity and its garnishment laws.

162 Ibid.

153 Hearings App. B. (Data supplied by Associated Credit Bureaus of California; the year is not indicated and the data only cover an unknown fraction of collection agencies. Not all states are covered.)

154 The data referred to in note 153 supra indicate a $36.3 \%$ recovery rate in New York as against $32.7 \%$ in California. Rates are below $20 \%$ in Arkansas (17.8\%), Texas $(15.2 \%)$, and North Carolina (12.3\%). They are also below $20 \%$ in Missouri (16.1\%) and West Virginia (18.9\%) where wage garnishments are available. Missouri, West Virginia, and Alabama $(21.9 \%)$ have a lower recovery rate than Pennsylvania $(23.1 \%)$, a state that does not permit wage garnisliments.

155 Nebraska, 39.3\%; New Jersey, 33.4\%. Hlinois also ranks above California in recoveries. Hearings App. B. 
kinds, judicial examination of judgment debtors, and other tools. ${ }^{156}$ Over the years "creditors have gained a vast arsenal of remedies."

\section{E. Garnishment and the Changing Pattern of Debt}

Garnishment statutes originated in an era when consumer credit was all but unknown. Until recently, debt.was something devoutly to be avoided; to "commit" debt was faintly, or not so faintly, immoral. To let creditors jeopardize a man's job by garnishing his wages is a manifestation of this attitude. The fifty per cent wage exemption is a sort of rough compromise between regarding the debtor as sinful and his family as unfortunate. ${ }^{158}$

The time when a family had few, if any, debts except perhaps a home purchase mortgage may be remembered nostalgically, but it has passed. The years following the end of World War II saw the development of what might be called the American way of debt. A trend toward the use of consumer credit, which started before the war, accelerated rapidly during the past two decades. To cite a few more numbers: in 1945, outstanding consumer credit totalled 5.7 billion dollars; in 1956, 42.3 billion dollars; in 1960, 56 billion dollars; and in December 1964, 76.8 billion dollars. ${ }^{169}$ These figures do not include mortgage indebtedness. Consumer credit has become a major industry and consumer debt consumes a major slice of many a family's income. Repayment of installment debt alone equalled fourteen per cent of disposable personal income in 1964. ${ }^{100}$ Installment credit makes up a large part, but not all, of

156 See generally Continutng Education of the Bar, Californta Remadeies for UNSECURED CREDITORS (1957).

157 Riesenfeld, Collection of Money Judgments in American Law, 42 IowA L. REv. 155,181 (1957).

158 This picture should not be drawn too broadly. Debtors, too, have had their innings in state legislatures; for instance in the enactment of anti-deficiency legislation governing mortgages. And states that have a $100 \%$ wage exemption have generally had it for a long time.

15951 FEd. ReSERVE Buda. 304 (February 1965).

160 Id. at 306, 319.

\begin{tabular}{|c|c|c|c|}
\hline \multirow[b]{2}{*}{ (In billions) } & \multicolumn{3}{|c|}{ Year } \\
\hline & 1962 & 1963 & 1964 \\
\hline Disposable personal income & 384.6 & 402.5 & 431.8 \\
\hline Installment credit extended & 55.1 & 60.8 & 66.1 \\
\hline Installment credit repaid & 50.6 & 55.1 & 60.4 \\
\hline
\end{tabular}

Installment credit does not include home purchase loans or noninstallment debts such as 30-day charge accounts.

If the amount of installment credit repaid is viewed in relation to compensation received by employees-a relation which may be more meaningful in case of lower and 
consumer credit, which also includes charge accounts, service credit, and single payment loans. ${ }^{101}$ Total consumer credit repayments are probably running at a level close to twenty per cent of clisposable personal income and well over twenty per cent of employees' earnings. ${ }^{102}$

Individual debt, not so long ago discouraged and regarded with suspicion, is now encouraged. More than encouraged, debt today is merchancised as intensively and skillfully as any commodity, notwithstanding occasional pious reminders to "never borrow money needlessly." The communications media that toucl a family's life constantly urge it to buy on "easy" terms, to open charge accounts with "nominal" monthly service charges, to get a new car at "bank" terms, to travel now and pay later-whether the family can afford it or not. The following report from The Wall Street Journal is illustrative:

Consider the case of the 24-year-old factory worker who last week walked into Courtesy Motors, a Chicago Ford dealership, just to look around. A salesman quickly-and politely-offered to help the unshaven young man but was met with what seemed to be a definitely negative reply. He had bought a new Rambler only 10 months ago and he still owed $\$ 1,800$ on it, the worker explained.

But two hours later, the young man purchased a new Galaxie two-door hardtop. "I really didn't expect to get a car today," he said somewhat bewildered, "but the salesman made it easy so I figured why not." Carl Shelby, the salesman, didn't find it so easy, though. "He owed too much on the Rambler to be a good credit risk," Mr. Shelby says.

The fact that the debt-laden factory worker was eventually approved points up another reason which many think plays a major role in the auto boom: Easy credit. Financing funds are so plentiful that it's a rare person who isn't able to work out some sort of installment arrangement, dealers say. Some buyers now can even get terms which allow them 42 months to pay for their new car.

"There's way too much credit," remarks Kenneth Grantham, owner of Kenray Ford, a Dallas car dealership. Then he adds quickly: "But I'm not complaining." For good reason, perhaps. Mr. Grantham's sales manager, Jesse James, estimates that " $90 \%$ of our customers are buying cars that they really can't afford. But credit is easy and people don't feel they're in the swing of things if they're not paying off a new car."163

middle income wage earners-we find that repayments are $17 \%$ of such compensation. Ibid. Compensation to employees (in billions): $1962-\$ 323.1,1963-\$ 340.3,1964-\$ 361.7$. 181 These items totaled $\$ 17.4$ billion in December 1964 and together with $\$ 59.4$ billion in installment credit made up the $\$ 76.8$ billion figure of outstanding consumer credit. Id. at 304 .

162 Disposable personal income includes income from sources other than employment. Compensation to employees was $\$ 361.7$ billion in 1964 . Id. at 318 .

163 Wall Street Journal, May 14, 1965, p. 1, col. 8. 
Evien with sales managers named Jesse James, one may grant that the contribution of consumer credit to the economy and to the standard of living of many families is substantial. But when personal debt is no longer unusual, no longer a sign of improvidence, when debt has imstead become a mass production, hard-sell item that citizens are widely encouraged to "buy," one may doubt the continued appropriateness of a device such as wage garnishment. Even when debt was a sin not all states allowed creditors to go after a man's wages. Today this harsh renedy, humiliating at best, disastrous to the debtor and his family at worst, seems far less justifiable than $\mathrm{m}$ an age when personal debt was uncommon and disfavored. It is time that our attitude toward wage garnishment-which is, after all, a drastic form of intervention by government on behalf of creditors-caught up with our attitude toward debt. ${ }^{164}$

Not all garnishnents result from the purchase of goods and services on credit, but the great bulk do. ${ }^{165}$ There are still deadbeats who merit no sympathy. Happily they appear to be few in number. ${ }^{166}$ In any event, weapons to pursue deadbeats should not be fashioned in a way that permits injury to others.

\section{III}

\section{CONCLUSTONS AND RECOMMENDATIONS}

Garnishment is a common collection tool in California. The tool is statutory. Its main-almost its exclusive-users are collection agencies. The great majority of debts that eventually lead to garnishments arises from the purchase of goods and services. In recent decades there has been a dramatic and thoroughly promoted move toward credit buying.

164 Along with the debt explosion there bave been other changes. While in an earlier period consumer credit, such as it was, mainly took the form of credit temporarily extended by the neighborhood store at little or no interest, much of consumer credit today involves large institutions, complex terms that the debtor cannot negotiate and often does not fully understand, and high interest. Of course, not every credit transaction is of this kind. There is also a good deal of selling to poor credit risks, see text accompanying note 163 supra, and to persons whose credit is not checked. See, e.g., FusFeID, op. cit. supra note 55 , at 7 .

165 See note 141 supra. The principal service that leads to garnishment-producing debts is medical and hospital care. It might be argued that doctors and hospitals are entitled to greater consideration-better collection remedies-than sellers of goods, because of the important humanitarian nature of their service and because unlike many sellers a doctor or a hospital has nothing to repossess. It can also be argued that users of medical and hospital care are entitled to more consideration than credit buyers of nuany goods. Medical credit is, of course, not a new development, but even in this area the trend has been toward more formalized and institutionalized credit arrangements. Credit institutions have become an increasingly important source of medical credit.

166 The delinquency rate on installment credit is between 1 and $2 \%$ of the amount of credit extended and the net loss rate is below that by an undetermined anount. These figures appear to be national averages. Not all losses are attributable to deadbeats or "credit criminals" as the collection industry sometimes calls then. See Hearings App. B. 
Collection agencies find wage garnishnent a useful tool, not only because of the debtor's earnings actually reached by levies, but because the threat of garnishment encourages the debtor to make payments. Whether one views this effect as persuasive or coercive depends to some extent on one's point of view. In any event, the encouragement is due to the debtor's fear that he will lose his job if there are nore garnishments. The fear is real. Discharges because of repeated wage levies are not uncommon. Employers dishike the added work and expense brought by levies and often limit the number of levies they will permit without discharge. Labor organizations have apparently not been able to bargain effectively on this issue.

The employee who is threatened with discharge, and who cannot pay, sometimes chooses bankruptcy as a means of saving his job. The expansion of consumer credit in the postwar years has been accompanied by a sharp rise in bankruptcies, particularly in nonbusiness bankruptcies. Bankruptcy rates tend to be lower in states that do not permit wage garmishment or that sharply restrict its use. Abolition of wage garnishment would not eliminate personal bankruptcies, but it could contribute significantly to stemming their rising tide.

Wage garnishment is costly. Its immediate costs include official fees -chargeable to debtors-expense to employers, and the community's subsidy of the garnishment process. There are other costs in terms of distress and economic hardship when the family whose earnings are garnished spirals into bankruptcy or unemployment. And there are losses to creditors from garnishment-triggered no-asset bankruptcies. Hardship is not limited to bankruptcy and unemployment; a debtor who avoids both is faced with a fifty per cent wage exemption, an amount that in the great bulk of cases is grossly inadequate.

Wage garnishment does not produce benefits to match these disadvantages. There is no evidence that the granting of credit depends on the availability of this tool. Economic data, even data supphed by collection agencies, show that the ratio of installment credit to retail trade is as high in states that do not permit garnishment as in states that do. The data show further that a state's volume of retail trade and its level of per capita income is unrelated to garnishment laws. This is not surprising in view of the creditor's full kit of tools, in which wage garnishment is only one of many. There are some data indicating that collection agencies tend to collect more of their claims in states that have wage garnishment than in states that do not. But the available information indicates more strongly that consumer credit and retail tracle in a state are unrelated to these collection rates. Further, collection data show that several states 
with a ninety per cent wage exemption have higher percentage recoveries by collection agencies than California.

\section{A. Legislative Proposals for Changes in California Wage Garnishment Statutes}

A number of bills designed to ameliorate the garnishment problem have been introduced in recent sessions of the California legislature.

A measure introduced in 1965 would have raised the basic exemption from fifty to eighty per cent. ${ }^{167}$ One 1963 proposal sought to exempt all earnings from garnishment; an amended version would have provided a one hundred per cent exemption from attachment and a seventy-five per cent exemption from execution with a maximum exemption of two hundred dollars a week. ${ }^{168} \mathrm{~A}$ second would have exempted forty dollars a week and seventy-five per cent of the balance for heads of families and ten dollars a week less for others. ${ }^{169} \mathrm{~A}$ third aimed at a one hundred per cent exemption from attachment without changing the execution provisions. ${ }^{170}$ This was also the objective of a fourth proposal, together with a barring of wage garnishments for two weeks after entry of judgment. ${ }^{171}$ While these measures were not enacted, the legislature adopted a resolution calling for a study of the existing California laws exempting personal property from attachment and execution of judgment and of the changes in the state's population and credit structure which could have a bearing on revision of the law. ${ }^{172}$ The Assembly Interim Judiciary Committee studied the subject and concluded:

[A] revision of the law which will increase the debtor's protection by way of exemption and which will make that protection more modern and equal will be of benefit to both debtors and creditors. This conclusion reflects the underlying fact that neither debtor nor creditor

167 Assembly Bill 2901 (1965) (introduced by Assemblyman Dymally). Two other bills were concerned only with attachment, one raising the minimum amount of a claim on which attachment can issue from $\$ 75$ to $\$ 125$, Assembly Bill 1127 (1965) (introduced by Assemblyman Danielson), the other requiring a second affidavit for attachment and a hearing within 72 hours to determine whether the property shall remain attached or be rcleased, Assembly Bill 3220 (1965) (introduced by Assemblyman Chapel). A.B. 1127 was enacted. Cal. Stats. 1965 , ch. $668, \S 1$. Neither it nor A.B. 3220 significantly affect the wage garnishment problem. A.B. 2901 and 3220 were not reported out by the committee to which they had been referred.

168 Assembly Bill 482 (1963) (introduced by Assemblyman Foran). The bill also would have provided a 50\% exemption from wage levies based on alimony and child support obligations. At present there is no exemption at all in such situations. See note 20 supra.

160 Assembly Bill 2278 (1963) (introduced by Assemblyman Foran), later amended by the author in a manner similar to Assembly Bill 482, note 168 supra.

170 Assembly Bill 2332 (1963) (introduced by Assemblyman Foran).

171 Assembly Bill 2808 (1963) (introduced by Assemblyman Ferrell).

172 H. Res. 268 (1963). 
benefits when the debtor is financially crippled. A more powerful exemption law will help keep the debtor from sinking further into a financial abyss and losing his job. At the same time it will protect the creditors to the extent that it allows the debtor to keep going and to avoid bankruptcy. Incidental credit grantors such as doctors, lawyers and small businessmen lose when a small loan company garnishes wages and causes the debtor to be fired or run for bankruptcy. A law with more exemption protection will encourage the commercial credit grantors to be more careful in choosing their credit risks. If the creditor will do this, he will reduce his bad debt losses. This induced care may result in some reduction of overall credit granted, but the reduction will probably be small and will be justified by the decrease in human misery caused by extreme credit problems. Finally, an exemption law can be tailored to encourage the debtor to find a program which will help him to find his way out of a bad financial situation and into a better one. ${ }^{173}$

The Judiciary Committee report made no specific proposals.

\section{B. Recommendations}

Wage garmishment should be abolished as a harmful and unnecessary collection device. If a more conservative approach is preferred, the exemption should be made adequate and the use of garnishment carefully restricted so as to minimize its undesirable consequences. Specifically:

(1) Wage garnishment should not be permitted prior to judgment, that is, under writs of attachment. Even collection agencies agree that garnishment before judgment is unfair. ${ }^{174} \mathrm{How}$ nuch the defendant owes and, indeed, whether he owes anything is undetermined until judgment is entered.

(2) After judgment, ninety per cent of earnings should be automatically exempt. A debtor in average circumstances needs at least that much of his wages to avoid undue hardship and to stay relatively current on his obligations. The income of debtors varies and it is tempting to scale the exemption to income (for example, one hundred per cent of the first four hundred dollars per inonth, ninety per cent of the next two hundred dollars and seventy-five per cent of the excess). This is not recommended because such a provision is bikely to require frequent revision as the cost of hiving rises; without revision it will tend to give less and less protection. Also, as already noted, it is more complex to administer and can involve uncertamties of computation; the employers' interests are entitled to consideration here.

(3) The remaining ten per cent should be garnishable after judgment under the following conditions: (a) No garnishment would be permitted where the underlying indebtedness arose from installment credit, whether

173 Assembty Intertar Comar. on Judictarg, Finat Reporx 50 (Jan. 1965).

174 Note 43 supra. 
in the form of a loan or purchase. ${ }^{175}$ It is the occasional, small creditorif anyone--who might need the garnishment remedy. (b) Garnishment on other obligations could be had only after notice and a hearing. (c) At the hearing the court would consider the debtor's financial circumstances as well as the nature of the indebtedness involved. (d) The court would have discretion to order up to (and including) ten per cent of the defendant's earnings applied on the judgment. This would introduce a desirable measure of flexibility into the garnishment procedure. The court would retam jurisdiction and power to modify its order. (e) An execution levied against earmings pursuant to such an order would remain in effect until the judgment is paid. In other words, a single levy would suffice, thereby greatly reducing the expenses involved. Only one such execution would be allowed to be in effect at one time, otherwise the exemption could be defeated.

It is anticipated that the recommended changes would reduce the number of garnishments sufficiently so as to obviate the need for prohibiting discharges based on garnishments. However, that would be the case only if the substance of the recommendations were to be enacted. Particularly important is the proposed limitation of garnishment to obligations that do not arise from installment credit transactions. Without such a himitation garnishments are hikely to continue in substantial numbers, and serious consideration of steps to provide direct protection against garnishment-caused discharge would be necessary.

(4) If it is desired, as the Judiciary Committee report suggests, ${ }^{176}$ to help debtors work out a progran of paying off their debts, provisions similar to the Ohio trusteeship statute could be enacted. ${ }^{177}$ However, we should proceed cautiously before putting the State into the debt pooling business. The desirability of trusteeship depends at least in part on whether private facilities are adequate (and, if not, whether the development of more adequate ones can be encouraged) and whether the Bankruptcy Act's chapter 13 proceedings can be made more available to the average person in financial difficulties. It depends, too, on whether the California courts would welcone sucli a function-their wholeliearted co-operation would be essential - and on whether society is willing to subsidize the expense of operating trusteeships to a sufficient extent to encourage its use. The answers to these questions are debatable. Trusteeship Inay merit further thouglitful consideration, but that should not delay moving ahead on the other recommendations.

175 Compare the Delaware and South Carolina provisions, text accompanying notes 36,37 supra. These have substantially the same effect and their wording could be adapted for California use.

176 Note 173 supra.

177 Note 77 supra and accompanying text. But see note 105 supra. As to the Michigan conciliation procedure, see note 76 supra and accompanying text. 
APPENDIX A

AMOUNT OF WAGES EXEMPTED FROM GARNISHMENT, BY STATES

Alabama

Alaska

Arizona

Arkansas

California

.Colorado

Connecticut

Delaware

District of Columbia

Florida

Georgia

Hawaii

Idaho

Illinois

Indiana

Iowa
$75 \%{ }^{178}$

$\$ 350$ (earned within 30 days) if married; $\$ 200$ if single (170 $^{2}$ $50 \%$ (30 days) 180

$100 \%$ (60 days) ${ }^{181}$

$50 \%$ (30 days); $100 \%$ where debt not for necessaries and needed to support debtor's family 182

$70 \%$ for heads of families; $35 \%$ for single persons ${ }^{188}$

$100 \%$ from attachment; post-judgment exemption set by court (minimum $\$ 25$ per week) ${ }^{184}$

$90 \%$ (New Castle County); 60\% (Kent and Sussex Counties) ${ }^{185}$

$90 \%$ of first $\$ 200$ per month, $80 \%$ of next $\$ 300,50 \%$ of balance ${ }^{188}$

$100 \% 187$

$\$ 3$ per day plus $50 \%$ of excess ${ }^{188}$

$95 \%$ of first $\$ 100$ per month, $90 \%$ of next $\$ 100,80 \%$ of balance ${ }^{189}$

$50 \% ; 75 \%$ where debt not for necessaries and needed to support debtor's family (30 days); maximum exemption $\$ 100$ per month 180

$85 \%$ or $\$ 45$ per week, whichever is more; maximum $\$ 200$ per tweek ${ }^{191}$

$\$ 15$ per week plus $90 \%$ of excess ${ }^{102}$

$\$ 35$ per week for head of family plus $\$ 3$ for each dependent child under $18^{193}$

178 ALA. Code tit. 7, § 630 (1960).

179 AtaSKa StaT. \& 09.35.080 (1962).

180 ARIz. REv. StaT. ANN. §§ 12-1594, 33-1126 (1956).

181 If the wages plus personal property owned do not exceed $\$ 500$ for married residents or heads of families or $\$ 200$ for single residents. ARK. Const. art. 9, §§ 1-2; ARK. STat. $\$ 30.207$ (1962).

182 Cac. Code Civ. Proc. \$ 690.11.

183 Colo. Rev. Stat. \& 77-2-4 (1963).

184 Conn. Gen. Stat. Rev. \& 52-361 (Supp. 1964).

185 DEx. Code ANn. tit. 10, §§ 4913(b), (c) (1953). In New Castle County, wages in excess of $90 \%$ can only be reached for necessaries. See text at note 36 supra.

186 D.C. CODE ANN. § 16-572 (Supp. 1965).

187 Limited to resident heads of families. FLA. STAT. $\$ 222.11$ (1963). A number of states limit the exemption to residents or to heads of families or to cases where there is a showing that the portion claimed exempt is necessary for the support of the debtor's family or to combinations of these factors. E.g., Iowa and Kansas, notes 193, 194 infra. Such limitations will not generally be noted.

188 GA. CODE ANN. \$ 46-208 (Supp. 1963).

180 HAWAII REv. Laws § 237-1 (Supp. 1963).

190 IDADO CODE ANN. \& 11-205(7) (1947).

191 Irr. Rev. Stat. § 62-73 (1963). For garnishment procedure see, ILI. Rev. Stat.

§ 11-21 (1963).

192 IND. ANN. Stat. § 2-3501 (1946). But cf. IND. ANN. STaT. § 3-505 (1946); see

Pomeroy v. Beach, 149 Ind. 511, 49 N.E. 370 (1898).

193 Iowa CODE $\S 627.10$ (1958). No creditor may garnish for more than $\$ 150$ plus costs. 
Kansas

Kentucky

Louisiana

Maine

Maryland

Massachusetts

Michigan

Minnesota

Mississippi

Missouri

Montana

Nebraska

Nevada

New Hampshire
$90 \%$ (3 months); $100 \%$ from garnishment by collection agencies $^{194}$

$90 \%$ of first $\$ 75$ per month; maximum $\$ 67.50^{195}$

$80 \%$; minimum $\$ 100$ per month ${ }^{106}$

$\$ 30$ (one month); minimum $\$ 10^{197}$

$75 \%$ in some counties; $\$ 100$ in others 198

$100 \%$ prior to judgment; $\$ 50$ per week after judgment ${ }^{199}$ $100 \%$ prior to judgment; 200 after judgment $60 \%$ for houscholders having a family, $40 \%$ for others, with certain minima and maxima ${ }^{201}$

$50 \% ; 100 \%$ (30 days) where necessary for use of family ${ }^{202}$

$\$ 100$ for heads of families; $\$ 50$ for single persons ${ }^{203}$

$90 \%$ for heads of families 204

$50 \%$ (45 days); $100 \%$ where debt not for necessaries and needed for use of debtor's family ${ }^{205}$

$90 \%$ for heads of families ${ }^{206}$

$50 \%$ (30 days); $100 \%$ where debt not for necessaries and needed for use of debtor's family 207

$\$ 20$ per week ${ }^{208}$

104 Kan. Gen. Stat. ANn. § 60-2310 (1964).

$195 \mathrm{KY}$. REv. STAT. $\$ \$ 427.010$ (2), (3) (1962).

196 LA. REv. Stat. tit. 13, \& 3881 (1964).

197 ME. Rev. Stat. tit. 14, ch. $501 \S 2602$ (6) (Supp. 1965).

198 MD. ANN. Code art. 9, §§ 31, 31A, 31B; art. 83, § 8 (Supp. 1965).

199 Mass. GeN. Laws ch. 246, §§ 28, 32 Eighth (Supp. 1964).

200 MTCH. Stat. ANrs. § 27A.4011(3) (1962). But see note 55 supra.

201 The Michigan wage exemption is the most complex of any state:

\begin{tabular}{|c|c|c|c|c|c|c|}
\hline & \multicolumn{3}{|c|}{ Householders } & \multicolumn{3}{|c|}{ Others } \\
\hline & \multirow{2}{*}{$\begin{array}{l}\text { Percent } \\
\text { Exempt }\end{array}$} & \multicolumn{2}{|c|}{ Dollars } & \multirow{2}{*}{$\begin{array}{l}\text { Percent } \\
\text { Exempt }\end{array}$} & \multicolumn{2}{|c|}{ Dollars } \\
\hline & & Max. & Min. & & Max. & Min. \\
\hline \multicolumn{7}{|l|}{ First garnishment: } \\
\hline Wages for one week or less & $60 \%$ & $\$ 50$ & $\$ 30$ & $40 \%$ & $\$ 50$ & $\$ 20$ \\
\hline Wages for more than one week & 60 & 90 & 60 & 40 & 50 & 20 \\
\hline \multicolumn{7}{|l|}{ Suhsequent garmishments: } \\
\hline Wages for one week or less & 60 & 30 & 12 & 30 & 20 & 10 \\
\hline Wages for one week to 16 days & 60 & 60 & 24 & 30 & 20 & 10 \\
\hline Wages for more than 16 days & 60 & 60 & 30 & 30 & 20 & 10 \\
\hline
\end{tabular}

See Mrce. Stat. ANn. \$§ 27A.7511 (2), (3), 27A.4031 (1962). Higher amounts may be exempted by the court where the defendant is making support payments. MicH. Star. Axr. $\S 27 A .7511(4)(1962)$.

202 MnNN. Stat. ANN. $\$ \$ 50.37(13), 575.05$ (Supp. 1964).

203 Miss. Code ANN. \$ 307 (Tenth) (Supp. 1964).

204 Mo. REv. STAT. \& 525.030 (1949).

205 Mont. Rev. Codes ANN. \& 93-5816 (1964).

208 Neb. Rev. Stat. \$ 25-1558 (1964).

207 NEv. Rev. Stat. § 21.090 (h) (1963).

208 N.H. Rev. Stat. ANN. \& 512:21 II (Supp. 1963). 
New Jersey

New Mexico

New York

North Carolina

North Dakota

Ohio

Oklahoma

Oregon

Pennsylvania

Rhode Island

South Carolina

South Dakota

Tennessee

Texas

Utah

Vermont

Virginia
90\%; minimum $\$ 18$ per week ${ }^{209}$

$75 \%$ for heads of families ${ }^{210}$

$90 \% 211$

$100 \%$ (60 days) where needed for use of debtor's family ${ }^{212}$

$\$ 35$ per week or, if head of family, $\$ 50$ plus $\$ 5$ for each dependent, but no more than $\$ 25$, per week ${ }^{218}$

$80 \%$ of first $\$ 300$ per month and $60 \%$ of balance for heads of families (minimum $\$ 150$ ); $\$ 100$ (30 days) for others ${ }^{214}$

$75 \%$ (90 days); $100 \%$ where needed to support family ${ }^{215}$ $\$ 175$ (30 days) ${ }^{218}$

$100 \%{ }^{217}$

$\$ 30^{218}$

$100 \%$ (60 days) where needed for use of debtor's family ${ }^{219}$

$100 \%$ (60 days) where needed for use of debtor's family 220

$\$ 17$ per week for head of family plus $\$ 2.50$ per week for each dependent under 16; $\$ 12$ per week for others ${ }^{221}$

$100 \% 222$

$50 \%$ (30 days); mimimum $\$ 50$ if married or head of family 223

$50 \%$ or $\$ 25$, whichever is less 224

$75 \%$; minimum $\$ 100$ per month, maximum $\$ 150$, for heads of families; for others $50 \%$ of the above $e^{225}$

209 N.J. REv. StaT. \$§ 2A:17-56, 17-50 (1951). Where the debtor's annual income exceeds $\$ 2,500$ the exemption may be reduced. N.J. Rev. STAT. \& 2A:17-56 (1951).

$21080 \%$ if the earnings for the past 30 days are less than $\$ 100$. N.M. STAT. ANw. § 26-2-27 (1965).

211 No income execution is permitted if the debtor's income is $\$ 30$ a week or less. N.Y. Civ. Prac. Laws \& Rules $\$ \S 5231(\mathrm{e}), 6202$. See Morris Plan Industrial Bank v. Gunning, 295 N.Y. 324, 67 N.E.2d 510 (1946).

212 N.C. Gen. Stat. § 1-362 (1953).

213 N.D. Laws 1965 , ch. 231 , \& 1 , at 449 .

214 O\#Iо Rev. Code ANw. $\$ 82329.66$ (F), 2329.62 (C), 2329.69 (Supp. 1964).

851 (1960).

215 OkJa. StaT. ANN. tit. 31, §§ 1 (16) (Supp. 1964), 4 (Fifth) (1955); tit. 12, §§ 850,

216 "[E]xcept that when the debt is incurred for fanily expenses 50 per cent of such earnings shall be subject to such execution or other process." OrE. Rev. STat. § 23.180 (1961).

21742 PA. Stat. tit. 42, § 886 (1930); see Lowe v. Jones, $414 \mathrm{~Pa} .466,200$ A.2d 880

(1964); Right Lumber Co. v. Kretchmar, 200 Pa. Super. 335, 189 A.2d 302 (1963).

218 R.I. GeN. LAws ANv. \& 9-26-4 (12c) (1956).

219 S.C. CODE \& 10-1731 (1962). But see text at note 37 supra. $\$ 1,500$.

220 S.D. CODE \& 33.2404 (Supp. 1960). Total exemption is apparently limited to

221 TENN. Code ANN. \$§ 26-207, 208, 209 (Supp. 1965).

222 TEx. Const. art. 16, § 28.

223 Utar COde ANN., § 78-23-1 (7) (1953); Utä Rev. Civ. Proc. rule 64c (a) (1953). 224 VT. STAT. ANN. tit. 12, \& 3020(5) (1958).

225 VA. CODE ANN. \$ 34-29 (Supp. 1964). The section adjusts the maxima and minima according to whether the debtor is paid weekly, biweekly, semimontbly or monthly. The 
Washington

West Virginia

Wisconsin

Wyoming

$\$ 35$ per week and $\$ 5$ for each dependent; maximum $\$ 50$ per week, for persons who have families dependent on them; $\$ 25$ per week for others 226

$80 \%$; mimimum $\$ 20$ per week ${ }^{227}$

$60 \%$ (30 days) with certain minima and maxima ${ }^{228}$

$50 \%$ (60 days) ${ }^{229}$

\section{APPENDIX B}

\section{TYPE AND FREQUENCY OF ATTACEMENT AND EXECUTTON} IEVIES IN 100 MUNICIPAT COURT CASES

Thirty-one of the cases resulted in levies of writs of attachment or execution; there were attachments in 17, execution in 21. (The total exceeds 31 because in several cases there were both attachments and executions.) Altogether these cases produced a total of 68 levies, at least 47 of them wage garnishments (with respect to some levies the file did not disclose whether it was a levy on wages or other property.) The types and frequency of levies may be summarized as follows:

\begin{tabular}{|c|c|c|c|c|c|}
\hline \multirow[b]{2}{*}{$\begin{array}{l}\text { Type of Property } \\
\text { Levied on }\end{array}$} & \multicolumn{2}{|c|}{ Attachment } & \multicolumn{2}{|c|}{ Execution 230} & \multirow{2}{*}{$\begin{array}{l}\text { Totals } \\
\text { Levies }\end{array}$} \\
\hline & $\begin{array}{l}\text { No. of } \\
\text { cases }\end{array}$ & $\begin{array}{l}\text { No. of } \\
\text { levies }\end{array}$ & $\begin{array}{l}\text { No. of } \\
\text { cases }\end{array}$ & $\begin{array}{l}\text { No. of } \\
\text { levies }\end{array}$ & \\
\hline Wages & 7 & 8 & 13 & 39 & 47 \\
\hline Bank accounts & 4 & 4 & 5 & 5 & 9 \\
\hline Cars or trucks & 1 & 1 & 1 & 2 & 3 \\
\hline Other personal prop- & & & & & \\
\hline erty and debts & $\cdot 1$ & 2 & 0 & 0 & 2 \\
\hline Real property & 1 & 1 & 1 & 1 & 2 \\
\hline Unknown & 3 & 3 & 2 & 2 & 5 \\
\hline TOTALS & 17 & 19 & $22 *$ & 49 & 68 \\
\hline
\end{tabular}

* In one case there were both wage levies and a levy on realty. Hence this total exceeds by one the figure previously given.

In five cases both writs of attachment and execution were used for wage levies. Thus, the total number of cases in which wage levies pursuant to either type of writ were made is 15 . The above figures are conservative simce the files do not always fully reflect all writs issued and levied.

section also makes it clear the $25 \%$ which may be garnished is $25 \%$ of the wages between the minimum and the maximum; therefore, the exemption is more accurately stated as $\$ 100$ per month plus $75 \%$ of the next $\$ 50$. The Virginia provision illustrates the problems that arise when dollar figures are used in exemption statutes: The section was amended in 1952, 1954, 1958, and 1960 in an effort to update the minima and maxima; it is still woefully out of date.

220 WASH. REv. CODE $\$ 7.32 .280$ (1964).

227 W. VA. CODE § 3834(3) (1961). West Virginia uses the term "suggest execution" for post-judgment wage levies. W. VA. CoDE $\$ 3834(1)$ (1961).

228 Wis. STAT. ANN. § 272.18 (15) (1958).

220 Wro. Stat. ANN. \& $1-422$ (1957).

230 Includes wage levies pursuant to California Code of Civil Procedure $\S 710$, which provides a procedure similar to execution for reaching the pay of employees of the state and its pohtical subdivisions. 